\title{
Phylogenetically vetted and stratigraphically constrained fossil calibrations within Aves
}

\author{
Daniel Ksepka and Julia Clarke
}

\begin{abstract}
Understanding the timing of the crown radiation of birds is a major goal of avian molecular systematists and paleontologists. Despite the availability of ever-larger molecular datasets and increasingly sophisticated methods for phylogeny reconstruction and divergence time estimation, relatively little attention has been paid to outlining and applying fossil calibrations. As the avian fossil record has become better sampled, and more extinct taxa have been incorporated into a phylogenetic framework, the potential for this record to serve as a powerful source of temporal data for divergence dating analyses has increased. Nonetheless, the desire for abundant calibrations must be balanced by careful vetting of candidate fossils, especially given the prevalence of inaccurate fossil calibrations in the recent past. In this contribution, we provide seven phylogenetically vetted fossil calibrations for major divergences within crown Aves representing the splits between (1) Anatoidea, (2) Sphenisciformes, (3) Coracioidea, (4) Apodidae, (5) Coliiformes, (6) Psittaciformes, and (7) Upupiformes, and the respective extant sister taxon for each of these clades. Each calibration is based an individual specimen, which maintains the clearest possible chain of inference for converting the relevant stratigraphic horizon to a numerical date. Minimum ages for each fossil are tightly constrained and incorporate associated dating errors, and the distributions of younger fossils from the clades of interest are summarized to provide a starting point for workers interested in estimating confidence intervals or outlining prior age distribution curves.
\end{abstract}

Daniel Ksepka. National Evolutionary Synthesis Center, Durham, North Carolina, 27706, USA. ksepka@nescent.org Current address: Bruce Museum, Greenwich, Connecticut 06830, USA

Julia Clarke. Department of Geological Sciences, Jackson School of Geosciences, The University of Texas at Austin, Austin, Texas 78713, USA. julia_clarke@jsg.utexas.edu

Keywords: divergence dating; molecular clock; birds

PE Article Number: 18.1.3FC

Copyright: Society for Vertebrate Paleontology February 2015

Submission: 14 January 2013. Acceptance: 14 October 2014

Ksepka, Daniel and Clarke, Julia. 2015. Phylogenetically vetted and stratigraphically constrained fossil calibrations within Aves. Palaeontologia Electronica 18.1.3FC; 1-25;

palaeo-electronica.org/content/fc-3

Calibrations published in the Fossil Calibration Series are accessioned into the Fossil Calibration Database (www.fossilcalibrations.org). The Database is a dynamic tool for finding up-to-date calibrations, and calibration data will be updated and annotated as interpretations change. In contrast, the Fossil Calibration papers are a permanent published record of the information on which the calibrations were originally based. Please refer to the Database for the latest data. 


\section{INTRODUCTION}

Divergence dating analyses can provide insight into the timing of evolutionary radiations, placing them in the context of plate tectonic events, climate shifts, and mass extinctions. Fossils provide a crucial source of temporal information that allows nodes in molecular trees to be tied to the geological time scale. As methods for divergence dating and their computer implementation have become more sophisticated, the importance of fossil calibrations has grown. The need for precise phylogenetic placement and stratigraphic constraint of these fossil calibrations is evident.

Birds have been frequent targets of divergence dating analyses (e.g., Hedges et al., 1996; Cooper and Penny, 1997; van Tuinen and Hedges, 2001; van Tuinen and Dyke, 2004; Shapiro et al., 2002; Ericson et al., 2006; Baker et al., 2007; Pereira et al., 2007; Brown et al., 2008; Pratt et al, 2009; Phillips et al., 2010; Pacheco et al., 2011; White et al., 2011). A common thread in these analyses has been testing whether the avian crown radiation was well underway during the Cretaceous, implying a wave of mass survivorship across the K-Pg boundary, or took place primarily in the Paleogene, implying an explosive radiation following the K-Pg mass extinction (reviewed by Penny and Phillips, 2004). Despite strong interest in avian divergence dating, there has been relatively little effort expended on explicitly justifying the phylogenetic placement of fossil calibrations for key nodes. The majority of avian fossils that have been applied as fossil calibrations have never been included in a phylogenetic analysis (Ksepka et al., 2011), and a substantial number have been applied to nodes that contradict the most recent placement of fossil taxa (e.g., Mayr, 2005a; Ksepka, 2009; Wijnker and Olson, 2009; Smith, in press). We suspect that many inaccurate calibrations can be attributed to the unwarranted assumption that fossil bird taxonomy reflects phylogeny, e.g., the misattribution of stem lineage fossils to extant families. Until recently, phylogenetic work on fossil members of the crown radiation of birds has been sparse, and the list of fossils that were formerly shoehorned into extant higher taxa is long (e.g., Olson, 1985; Mayr, 2009).

Inaccurate or imprecise ages have been tied to avian fossil calibrations as well. This is in part due to the complex chain of inference that must be applied to translate stratigraphic occurrences into numerical dates. Although early analyses often treated calibrations as point constraints or hard minima, many current divergence dating methods allow implementation of prior age distributions (e.g., Thorne et al., 1998; Yang and Rannala, 2006; Yang, 2007; Drummond et al., 2006; Drummond and Rambaut, 2007). Depending on the analysis, prior distribution curves may be narrow and multiple calibrations may strongly impact one another (e.g., Ho and Phillips, 2009; Inoue et al., 2010; Clarke et al., 2011; Warnock et al., 2012). For this reason, precision in fossil dating is recognized to be of crucial importance. Beyond this, stratigraphic revisions that occur subsequent to the initial description of a fossil are often overlooked, resulting in obsolete age estimates being retained in the systematic literature. One need only compare recent Cenozoic time scales (e.g., Gradstein et al., 2004, figure 1.7) to understand the magnitude of change in global geochronology over the past few decades, to say nothing of local revisions within individual formations.

In this paper, we lay out the justification for a set of fossil calibrations within the crown radiation of birds. We propose seven phylogenetically and stratigraphically constrained fossils from clades distributed widely across Aves. Our calibrations follow the best practice guidelines outlined by Parham et al. (2012) in (1) basing each calibration on an individual specimen, (2) referencing an apomorphy-based diagnosis or phylogenetic analysis including this specimen, (3) resolving any conflict between morphological and molecular data sets that affect the reliability of the fossil calibration,(4) providing the explicit stratigraphic context of the fossil, and (5) translating stratigraphic placement to a numerical date via connection to radiometric dates and/or the geological time scale. We further apply slightly stricter criteria in this contribution, recommending fossils as calibrations only if (1) the specimen comprises at least a partial skeleton, (2) the species has been included in a phylogenetic analysis, and (3) the gap between the age of the calibrating fossil and the next oldest representative of its clade spans less than $10 \mathrm{Ma}$. We do not take the position that fossils failing to meet these additional criteria should not be used as calibrations. However, given the history of single elements being erroneously assigned to extant clades and active disputes over the affinities of fossils in avian paleontology, increasing the threshold for the fossil calibrations presented here should ensure they are of maximum stability and reliability. Choosing relatively complete fossils has the added appeal of facilitating the application of methods that directly incorporate fossils as terminal taxa in divergence 
dating analysis (e.g., Ware et al., 2010; Pyron, 2011; Ronquist et al., 2012).

Several of the fossils discussed here have previously been used as calibrations. However, in each of these cases the calibration has been applied either to a different node or with a different minimum age (in some cases varying by several million years). Such discrepancies illustrate the strength of tying calibrations to an individual fossil specimen, and the importance of explicitly stating the justification for the placement and the age of each calibration point.

In outlining the justification for these calibrations, we discuss the current evidence for the higher-level relationships of the clade to which each fossil taxon belongs and how this may affect the utility of these calibration points. One crucial reason for considering higher-level relationships is that the sister taxon of the clade to which the fossil taxon belongs must be included in the divergence study in order for the calibration to be properly applied. In cases where relationships are unstable, this may require wide taxonomic sampling. If the sister taxon is not included in the analysis, the calibration age will be applied to a node deeper in the tree - a node that logically must predate the age of the divergence calibrated by the fossil. Results from analyses in which the sister taxon is omitted will thus be biased towards underestimating the age of clades throughout the entire tree under most methods. Additionally, examining alternate hypotheses of higher level relationships facilitates the identification of potential conflicts between morphological and molecular data sets that could alter the optimization of characters supporting the placement of the fossil (recommendation 3 of Parham et al., 2012).

We attempt to provide both the most accurate ages available for each calibrating specimen and a review of the fossil record over the 20-30 million years subsequent to the appearance of the calibrating specimen. The age of a phylogenetically vetted fossil can be treated as a hard minimum age for the most exclusive clade to which it belongs. Hard minimum calibrations, as well as prior age distributions that include a minimum bound, should utilize the youngest possible age of the fossil including the associated error, because this represents the minimum possible age of the fossil and because any method for further quantifying uncertainty should take the absolute minimum as a starting point (e.g., van Tuinen et al., 2004; Donoghue and Benton, 2007; Ho and Phillips, 2009). Advances in geochronology and revisions of ranges such as biozones are continually improving the accuracy and precision of age estimates. In translating global stratigraphic boundaries into numerical dates, we relied on the Geological Time Scale 2012 (Gradstein et al., 2012). However, in many cases we were able to access local stratigraphic data such as radiometrically dated ash layers to provide a more precise age constraint. By presenting not only the most recent age estimate for each fossil but also an explicit justification for this age, we hope to provide those interested in utilizing these fossil calibrations with a means of verifying the most up-to-date ages as dates for relevant biostratigraphic zones, paleomagnetic chrons, ash layers, and other such horizons are refined in the future.

Tabulating occurrences from deposits younger than the calibrating fossil is useful because it gives a sense of the completeness of the fossil record of the clade, and hence the uncertainty that needs to be taken into account when formulating prior age distributions or maximum constraints. Müller and Reisz (2005) emphasized that well-constrained calibration points should be based on fossils with no major gap between the oldest known specimen and the next oldest occurrences for the clade. In cases where this condition is not met, there is reason to suspect the clade in question may be significantly older, but poorly represented in the fossil record. As with any group, the continuity of the fossil record varies widely in different avian clades. For some clades, such as penguins, fossils are densely sampled across geologic time. In others, very wide gaps exist between the first fossil record and the next oldest exemplar. Fregatidae, for example, is known from multiple Early Eocene skeletons of the taxon Limnofregata, but has no subsequent fossil record until the Pleistocene (Olson, 1975, 1977). While Limnofregata still provides a minimum calibration point for the divergence of Fregatidae from other extant birds, there is little fossil evidence to inform the estimation of the maximum age of this divergence.

Stratigraphic occurrence data can be converted into confidence intervals or otherwise utilized to formulate maximum bounds for calibrations. However, such endeavors require taking factors such as predicted diversity, preservation, distribution of fossiliferous horizons, and sampling rates into account (e.g., Strauss and Sadler, 1989; Marshall, 1997, 1999; Reisz and Müller, 2004; Müller and Reisz, 2005; Marjanovíc and Laurin, 2008; Benton et al., 2009). Converting these occurrence charts into explicit confidence 
intervals or prior distributions is by no means straightforward. In this contribution, we provide occurrence data but forego recommending explicit maximum bounds or probability distributions.

\section{ANATOIDEA (DUCKS, GEESE, AND SWANS)}

Node Calibrated. Divergence between Anatidae and Anseranatidae.

Fossil Taxon. Vegavis iaai Clarke et al., 2005. Specimen. MLP 93-I-3-1 (Museo de La Plata, Argentina): partial skeleton including seven vertebrae, dorsal ribs, sacrum, scapula, coracoid, humerus, ulna, partial radius, pelvis, femora, tibiotarsus, and partial tarsometatarsi.

Phylogenetic Justification. Phylogenetic analysis of morphological data (Clarke et al., 2005).

Minimum Age. $66.5 \mathrm{Ma}$.

Age Justification. MLP 93-I-3-1 was collected from lithostratigraphic unit $\mathrm{K} 3$, also referred to as Unit "C" of Pirrie et al. (1991) or the Sandwich Bluff Member of the Lopez de Bertodano Formation (Pirrie et al., 1997; Crame et al., 1999, 2004) at Sandwich Bluff, Vega Island, Antarctica. A Late Maastrichtian age for the Sandwich Bluff Member is based on an array of biostratigraphic evidence. Abundant marine reptiles, a hadrosaurian dinosaur tooth, macro-invertebrates, and micro-invertebrates have been sampled from deposits directly overlying the concretionary layer that produced the Vegavis holotype (Pirrie et al., 1991; Case et al., 2000; Riding et al., 1992; Martin, 2006; reviewed in Clarke et al., 2005).

While a Maastrichtian age has been established for the Sandwich Bluff Member, some uncertainty remains in the correlation between the Maastrichtian Lopez de Bertodano deposits on Vega Island and the better studied sections on nearby Seymour Island. The Vegavis type horizon is placed near the lower base of the Manumiella bertodano (="Manumiella new species 2" of Pirrie et al., 1991) dinoflagellate biozone (Thorn et al., 2009). The Manumiella bertodano biozone is restricted to a limited portion of the Maastrichtian section on Seymour Island, bounded by a first appearance datum $\sim 200 \mathrm{~m}$ below the K-Pg boundary and a last appearance datum $50 \mathrm{~m}$ below the K-Pg boundary in the composite section (Thorn et al., 2009). Precisely estimating the amount of time represented by the $\sim 50 \mathrm{~m}$ stratigraphic interval between the top of the Manumiella bertodano biozone and the K-Pg boundary, and the amount of time represented by the stratigraphic interval between the base of the Manumiella bertodano biozone and the Vegavis holotype horizon will require further work. Correlations by Tobin et al. (2012), taking into account magnetostratigraphy, ${ }^{87} \mathrm{Sr} / 86 \mathrm{Sr}$ values and approximations of sedimentation rate, estimated the lower base of the Manumiella bertodano biozone to be approximately $67 \mathrm{Ma}$ in age. The top of this biozone $(50 \mathrm{~m}$ below the $\mathrm{K}$ $\mathrm{Pg}$ boundary) is estimated to be slightly younger than 66 Ma (e.g., Tobin et al., 2012, figure 4). These values were based on an estimated age of the $\mathrm{K}-\mathrm{Pg}$ boundary of $65.5 \mathrm{Ma}$. More recently, the age estimate of the K-Pg boundary has been refined to $66 \mathrm{Ma}$ (Renne et al., 2013). Thus, best estimates of these biozone boundaries should be shifted upwards by $0.5 \mathrm{Ma}$.

${ }^{87} \mathrm{Sr} / 86 \mathrm{Sr}$ chronology is suggestive of a slightly older date for the fossil horizon, but correlations remain uncertain. A $67.5 \mathrm{Ma}$ date from the Lopez de Bertodano Formation deposits on Seymour Island has been proposed to mark the Early/ Late Maastrichtian boundary (Crame et al., 2004). Sandwich Bluff Member deposits on Vega Island were illustrated as possibly correlative with Seymour deposits slightly older than those containing the 67.5 datum (Crame et al., 2004, figure 2). However, there is evidence that an unconformity underlying the Sandwich Bluff Member beds marks the $\sim 67.5$ Early/Late Maastrichtian transition on Vega Island, which would instead indicate a younger Late Maastrichtian age for the Sandwich Bluff Member (Crame et al., 2004, p. 420, and figure 3). Because the youngest possible age of the specimen should be used as the hard minimum calibration, we specify $66.5 \mathrm{Ma}$ for the calibration age.

Phylogenetic Position of Anatidae. Anseriformes comprises three major clades: Anhimidae, Anseranatidae, and Anatidae (Figure 1). A sister group relationship between Anseranatidae and Anatidae among extant Anseriformes has been supported by most morphological (Ericson, 1997; Livezey, 1997; Clarke et al., 2005; Livezey and Zusi, 2006, 2007) and molecular (Harshman, 1994; Cracraft et al., 2004; Hackett et al., 2008) analyses of extant Anseriformes. Because both classes of data agree on the phylogenic arrangement of the three major anseriform clades, the position of Vegavis is not subject to uncertainty arising from morphological / molecular conflicts. The extinct anseriform clade Presbyornithidae and Vegavis are both supported as being more closely related to Anatidae than to Anseranatidae (Ericson, 1997; Livezey, 1997; Clarke et al., 2005). Thus, Presbyornithidae and Vegavis are both included in the clade Anatoidea (Anatidae plus stem lineage relatives), though 


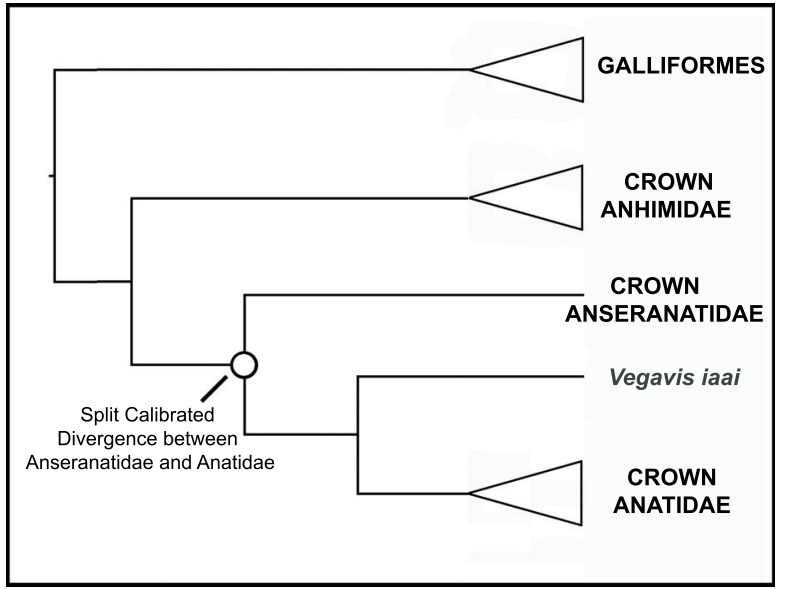

FIGURE 1. Phylogenetic tree showing the position of Vegavis iaai, illustrating the divergence calibrated by MLP 93-I-3-1.

whether they are each other's sister taxa remains uncertain.

Fossil Record of Anatoidea. Vegavis is the only Cretaceous fossil definitely supported as part of the crown radiation of birds by phylogenetic analysis. Specimens assigned to the Presbyornithidae are among the oldest known fossils that have been interpreted as crown clade birds. Teviornis gobiensis from the Late Cretaceous Nemegt Formation of Mongolia was also assigned to Presbyornithidae (Kurochkin et al., 2002). However, this species is known only from a few wing elements, and its affinities remain controversial (Clarke and Norell, 2004; Kurochkin and Dyke, 2010). If anseriform affinities were confirmed, Teviornis gobiensis would not greatly alter our proposed calibration age for the Anseranatidae-Anatidae divergence. The Nemegt deposits are generally interpreted as Maastrichtian (69-70 Ma., e.g., Averianov and Sues, 2012) but these fluvial deposits are much more poorly constrained in age than the marine Antarctic sequence. An additional Nemegt wing element showing morphological similarities to Presbyornithidae was not considered referable on the basis of apomorphy (Clarke and Norell, 2004).

Less controversial specimens assigned to Presbyornis occur at many Paleocene-Eocene localities in North America, South America and Asia. Oldest among these specimens is a wing element from the early/middle Paleocene of Maryland (Olson, 1994). In a review of Presbyornithidae, Ericson (2000) listed well-preserved specimens from a number of latest Paleogene-Eocene localities from the western United States (Feduccia and McGrew, 1974; McGrew and Feduccia, 1974; Olson and Feduccia, 1980; Benson, 1996) as well as a partial skeleton and isolated elements from Argentina (e.g., Telmabates; Howard, 1955; Cracraft, 1970). Paleogene Asian records of Presbyornithidae include isolated elements collected from latest Paleocene and Early Eocene horizons of the Naran-Bulak Formation of Mongolia (Kurochkin and Dyke, 2010). Aside from Vegavis and Presbyornithidae, the Paleogene record of taxa that can be placed along the stem lineage leading to Anatidae is relatively sparse, and the oldest accepted records are bones from the Late Eocene of France assigned to Romainvillia stehlini (Lebedinsky, 1927; Mayr, 2008a) (Figure 2).

Mayr (2013a) considered the placement of Vegavis iaai within crown Anseriformes to be problematic because of concerns over homoplasy in one character used to support this placement: presence of well well-developed cristae/sulci of the hypotarsus. Specifically, Vegavis exhibits a series of three shallow grooves in the hypotarsus (Clarke et al. 2005). Mayr (2013a) proposed that a similar morphology is present in some fossil stem representatives of Gaviiformes and Phoenicopteriformes, which would raise concerns over the reliability of this character. Although several taxa outside of Anseriformes exhibit the presence of three hypotarsal sulci, none show precisely the morphology observed in Vegavis. In the stem loon and stem flamingo taxa discussed by Mayr (2013a), the outer hypotarsal crests are more wellprojected and quite distinct from the condition in Vegavis and Anatidae, in which the crests are nearly equally well-projected. Although most medial crest is abraded in the Vegavis holotype, it appears to have been only slightly more projected than the lateral crest, as in most other Galloanserae.

Phylogenetic placement of Vegavis relies not only on characters of the hypotarsus, but also on a set of unambiguously optimized synapomorphies that nest this taxon within Aves, Neognathae, and Anseriformes (Clarke et al., 2005). Characters specifically supporting referral to Anatoidea (Anatidae + Anseranatidae) include absence of a sternal pneumatic foramen, apneumatic coracoid, ovoid $\mathrm{m}$. scapulohumeralis cranialis scar, and metatarsal II significantly shorter than metatarsal IV in distal extent. Addition characters are optimized as ambiguous synapomorphies of a clade uniting Vegavis, Presbyornis and Anatidae due to missing data in the Eocene fossil taxon Anatalavis. These include absence of a pneumatic foramen on the proximomedial surface of ribs and the presence of numerous hypotarsal cristae. 


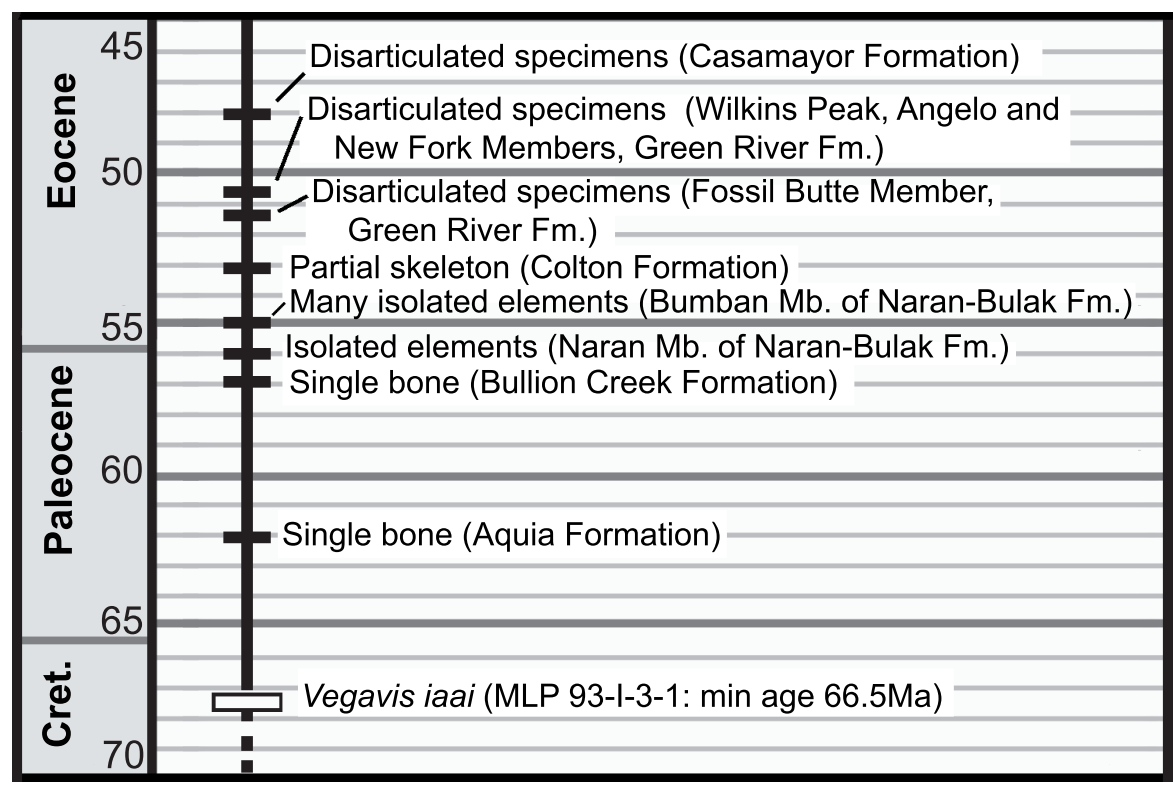

FIGURE 2. Stratigraphic distribution of fossil anatoids in the Paleogene. The minimum possible age of the calibrating specimen of Vegavis iaai is presented, and midpoints of age ranges are shown for the ages of other Paleogene anatoid specimens.

We note that no phylogenetic analyses have supported a close relationship between Vegavis and Phoenicopteriformes, Gaviiformes, or any other avian clade. Indeed, a placement within Neoaves would actually require a far greater level of diversification by the end of the Cretaceous than our recommended calibration placement within Anseriformes. Undoubtedly, these alternate placements would require higher levels of skeletal homoplasy as well. As with any fossil taxon, the discovery of new material or new analyses could shift the position of Vegavis. At present, however, we see no cause for concern with this calibration point given the phylogenetic support and the just younger Paleocene/Eocene crown anseriform fossils are known exhibit an array similar morphologies.

Fossil Record of Related Clades. Anseranatidae are known from only a few specimens, the oldest of which is a humerus from the Hornerstown Formation that is latest Late Cretaceous or earliest Paleocene in age (Olson and Parris, 1987; Parris and Hope, 2002). A partial skeleton of Anatalavis oxfordi from the Early Eocene of the United Kingdom (Olson, 1999) represents a more complete specimen. However, the phylogenetic affinities of this taxon remain controversial, and it has been alternatively considered a stem representative of Anseranatidae (Olson, 1999; Mayr, 2008a) or the sister taxon of the clade uniting Vegavis, Presbyor- nithidae, and Anatidae (Dyke, 2001a; Clarke et al., 2005). Two bones from the Late Oligocene or Early Miocene of Riversleigh, Australia, are the only other confirmed records on Anseranatidae (Worthy and Scanlon, 2009). Anseranatidae are today represented only by a single species, the Magpie Goose Anseranas semipalmata, which begs the question of whether this clade has been species poor since the time of their divergence from Anatidae. If this were so, it would partially explain the sparse fossil record of the group.

\section{SPHENISCIFORMES (PENGUINS)}

Node Calibrated. Divergence between Sphenisciformes and Procellariiformes.

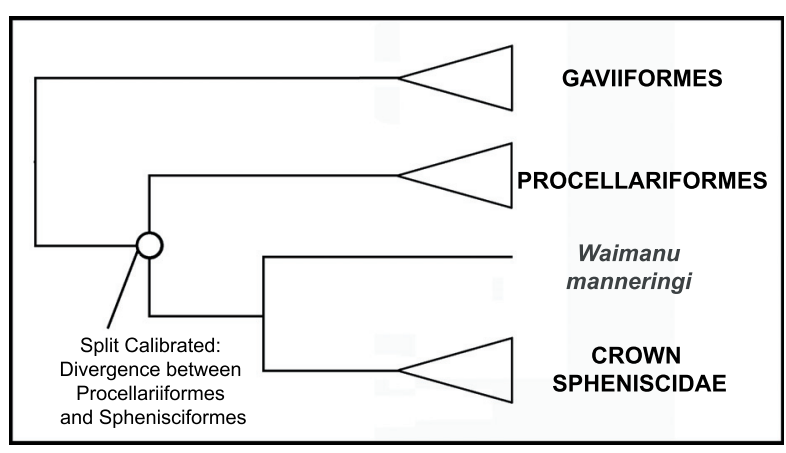

FIGURE 3. Phylogenetic tree showing position of Waimanu manneringi, illustrating the divergence calibrated by $\mathrm{CM}$ zfa35. 
Fossil Taxon. Waimanu manneringi Ando, Jones, and Fordyce, 2006 (in Slack et al., 2006)

Specimen. CM zfa35 (Canterbury Museum, Christchurch, NZ), holotype of Waimanu manneringi: thoracic vertebrae, caudal vertebrae, pelvis, femur, tibiotarsus, and tarsometatarsus.

Phylogenetic Justification. Waimanu was recovered as the most basal penguin taxon by multiple analyses using morphological data (Slack et al., 2006) and combined (morphological plus molecular) data (Ksepka et al., 2006, 2012; Clarke et al., 2007, 2010; Ksepka and Clarke, 2010a). No alternative hypothesis has been proposed linking Waimanu to any group other than Sphenisciformes.

Minimum Age. $60.5 \mathrm{Ma}$.

Age Justification. The only described specimen of Waimanu manneringi was collected from the basal Waipara Greensand (Slack et al., 2006). The top of the Waipara Greensand marks the Paleocene-Eocene boundary, placing the fossil well within the Paleocene. Calcareous nannofossils further constrain this locality's age. The last appearance datum for Hornibrookina teuriensis is no younger than early Selandian $(60.5 \mathrm{Ma})$, and the overlap between the ranges of Hornibrookina teuriensis and Chaismolithus bidens spans 60.5-61.6 Ma (Cooper, 2004; Slack et al., 2006; Ogg et al.,
$2008)$. The youngest possible age $(60.5 \mathrm{Ma})$ is used as a hard minimum age.

Phylogenetic Position of Sphenisciformes. A sister group-relationship between Sphenisciformes and Procellariiformes (Austrodyptornithes of Yuri et al., 2013) is supported by the largest published morphological (Livezey and Zusi, 2006, 2007) and molecular (Hackett et al., 2008) datasets for avian phylogeny (Figure 3). Alternative hypotheses include a sister group relationship between Sphenisciformes and a core clade of 'Pelecaniformes', supported by analysis of sequence data from the beta-fibrinogen gene (Fain and Houde, 2004) and morphological characters (Mayr, 2005b); a sister group relationships between Sphenisciformes and Podicipediformes + Gaviiformes recovered by analysis of morphological data (Smith, 2010); and a sister group relationship between Sphenisciformes and Ciconiiformes recovered from some analyses of mitochondrial data (Slack et al., 2003; Harrison et al., 2004; Watanabe et al., 2006). Notably, all of these taxa are supported as part of a large waterbird clade by most recent analyses (Ericson et al., 2006; Livezey and Zusi, 2006, 2007; Hackett et al., 2008; Morgan-Richards et al., 2008; Pratt et al., 2009). We consider a sister group relationship between Sphenisciformes and Procellariiformes to be the most

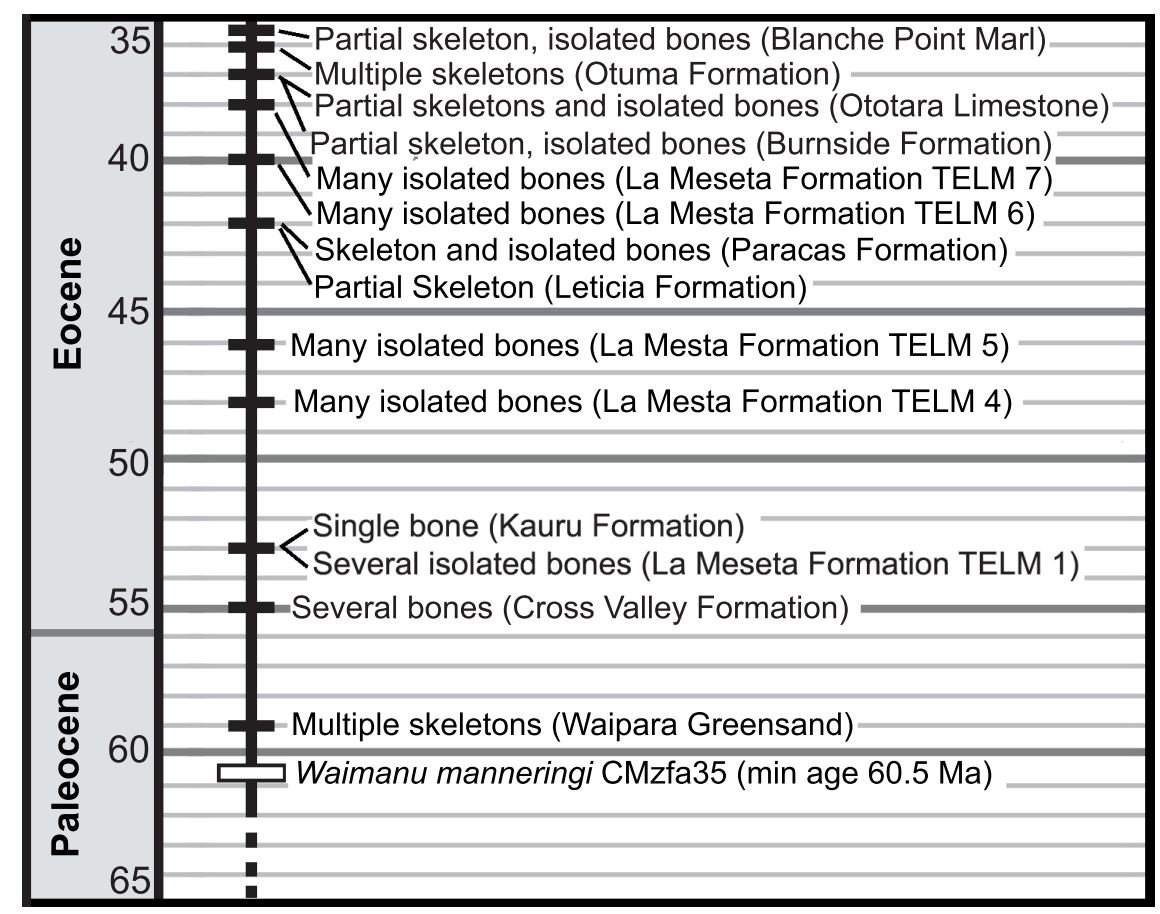

FIGURE 4. Stratigraphic distribution of fossil Sphenisciformes in the Paleogene. The minimum possible age of the calibrating specimen of Waimanu manneringi is presented, and midpoints of age ranges are shown for the ages of other Paleogene penguin specimens. 
well-supported hypothesis. We note, however, that the position of Waimanu manneringi on the penguin stem lineage does not hinge upon this topology. That is, the polarization of the many synapomorphies that place this species along the penguin stem lineage do not rely on the assumption that Procellariiformes are the closest living relative of penguins.

Fossil Record of Pan-Sphenisciformes. Although Waimanu manneringi is known only from the holotype specimen, the slightly younger ( $\sim 58-$ $60 \mathrm{Ma}$ ) Waimanu tuatahi is represented by multiple specimens that together comprise almost the entire skeleton, further supporting the presence of Sphenisciformes in the Paleocene (Slack et al., 2006). An additional late Paleocene ( 56 Ma) record is provided by a few elements described as Crossvallia unienwillia (Tambussi et al., 2005; Jadwiszczak et al., 2013). The Early-Middle Eocene record of penguins includes several dozen isolated elements dated to $\sim 49 \mathrm{Ma}$ from Seymour Island, Antarctica (Myrcha et al., 2002; Jadwiszczak, 2006a, 2006b; Jadwiszczak et al. 2013; Tambussi et al., 2006), a humerus from the Waipwan-Mangaorapan (50$56.5 \mathrm{Ma}$ ) of New Zealand (Fordyce and Thomas, 2011) and several partial skeletons and individual bones from the Middle Eocene of South America (Clarke et al., 2003, 2007). By the Late Eocene, penguins are distributed throughout much of the Southern Hemisphere and abundant in many localities (reviewed by Fordyce and Jones, 1990; Ksepka and Clarke, 2010a).

The absence of substantial gaps in the early record of penguins, their relatively high preservation potential (due to dense bones and occurrence in shallow marine environments), and support for an area of origin in New Zealand (Slack et al., 2006; Thomas et al., 2011) all suggest that the appearance of penguins in the fossil record closely corresponds at least to the timing of their shift to a flightless marine ecology, if not to their split from their sister taxon Procellariiformes (Figure 4).

Fossil Record of Related Clades. Procellariiformes have a shallower and more sparsely sampled fossil record than Sphenisciformes. Possible Paleogene records of Procellariiformes have been put forward, but these were based on partial limb bones and considered tentative even by the original describers (Olson and Parris, 1987; Hope, 2002). One of these fossils, Tytthostonyx glauconiticus, was later considered to represent a possible stem tropic bird by Bourdon et al. (2008). The Paleogene Eopuffinus kazachstanensis is known only from a cranial fragment (Nessov, 1992).
Though more material is required to confirm this identification, it is not directly relevant to the Sphenisciformes-Procellariiformes minimum age calibration because Waimanu manneringi is older. Eocene records of Procellariiformes are likewise scrappy, limited to a few isolated bones (Tambussi and Tonni, 1988; Feduccia and McPherson, 1993; Mayr and Smith, 2012). Early Oligocene records include the first good specimens, among them complete skeletons of the extinct clade Diomedeoididae (Fischer, 1985; Olson, 1985; Cheneval, 1995; Peters and Hamedani, 2000; De Pietri et al., 2010). Given the extensive nature of the penguin record and the higher preservation potential of thick-boned diving birds, longer gaps in the fossil record of Procellariiformes should be of little concern.

\section{CORACIOIDEA \\ (ROLLERS AND GROUND ROLLERS)}

Node Calibrated. Divergence between Coracioidea (Coraciidae and Brachypteraciidae) and their extant sister taxon (see discussion).

Fossil Taxon. Primobucco mcgrewi Brodkorb, 1970

Specimen. USNM 336484 (National Museum of Natural History, Smithsonian Institution, Washington DC, USA): nearly complete semi-articulated skeleton lacking left hindlimb. Multiple specimens of Primobucco mcgrewi exist from the same locality as USNM 336484 (Ksepka and Clarke, 2010b), which we select due to its completeness and preservation of key apomorphies.

Phylogenetic Justification. Phylogenetic analysis of morphological data (Mayr et al., 2004) and combined morphological and molecular data (Clarke et al., 2009).

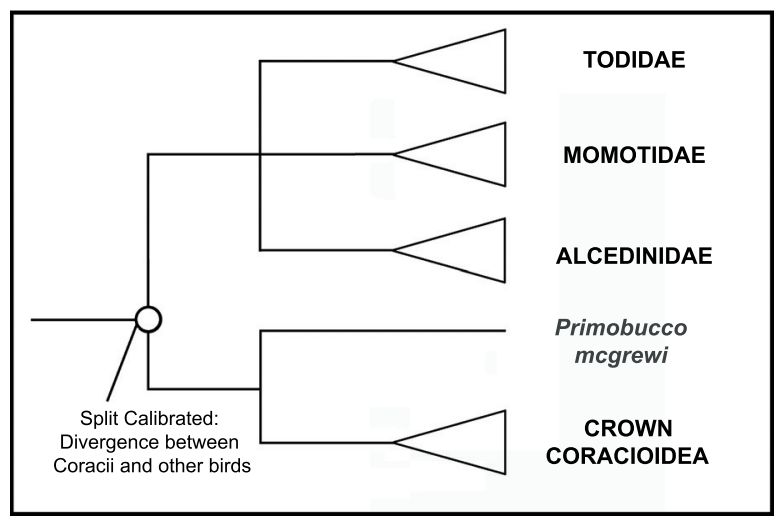

FIGURE 5. Phylogenetic tree showing position of Primobucco mcgrewi, illustrating the divergence calibrated by USNM 336484. 


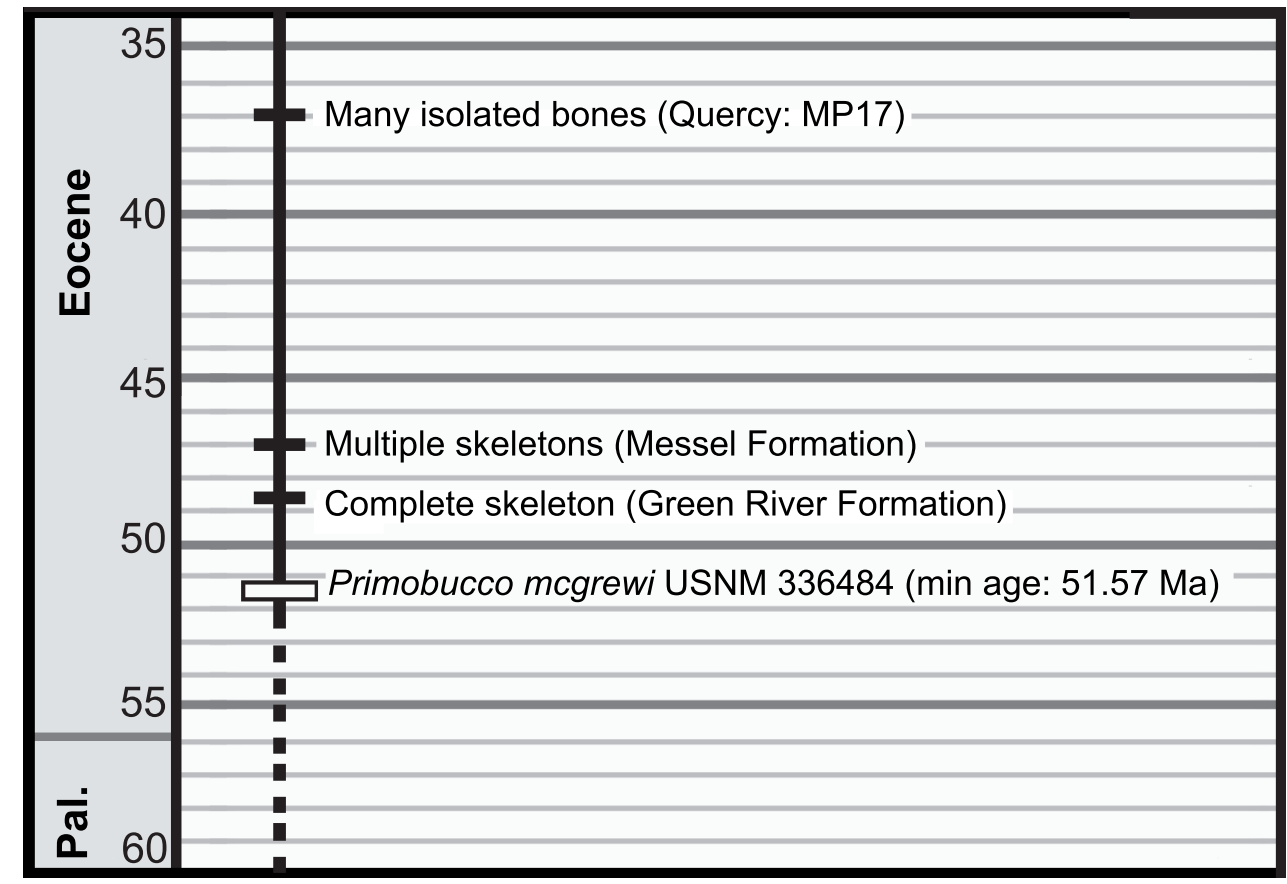

FIGURE 6. Stratigraphic distribution of fossil Coracii in the Paleogene. The minimum possible age of the calibrating specimen of Primobucco mcgrewi is presented, and midpoints of age ranges are shown for the ages of other Paleogene roller in specimens. A precise stratigraphic placement for the Condé-en-Brie specimen is not available (see text).

Minimum Age. 51.57 Ma.

Age Justification. USNM 336484 was collected from the Middle unit of the Fossil Butte Member of the Green River Formation in Wyoming, USA. The minimum date of $51.57 \mathrm{Ma}$ incorporates the error associated with $\mathrm{an}^{40} \mathrm{Ar} /{ }^{39}$ Ardate of $51.66 \pm 0.09$ Ma obtained from a potassium-feldspar (K-spar) tuff above the fossiliferous horizon containing USNM 336484 (Smith et al., 2008). Because the tuff was deposited several meters above the fossil horizon, this date can be appropriately treated as a hard minimum. There is no evidence of a substantial temporal gap between the fossil horizon and the tuff (Grande and Buchheim, 1994), and so we conservatively consider time elapsed between the deposition of the fossil and the tuff negligible for the purposes of defining a minimum age.

Phylogenic Position of Coracii. Coracii (rollers and their stem lineage relatives) are supported as part of a large clade that includes Alcedinidae, Momotidae, Todidae, Upupiformes, Bucerotiformes, and Piciformes (Ericson et al., 2006; Hackett et al., 2008; Pratt et al., 2009). Which of these taxa form the sister group of Coracii is not yet completely resolved. Supported candidates include a Todidae + Momotidae + Alcedinidae clade (Hackett et al., 2008), Meropidae (Livezey and Zusi, 2006, 2007 - note that this analysis also placed Leptoso- midae within Coracii), or all these taxa together (Clarke et al., 2009). Placement of Primobucco mcgrewi along the roller stem lineage can be considered relatively secure. Even though analysis of a combined dataset resulted in a different arrangement of the "Coraciiformes", Upupiformes + Bucerotiformes, and Piciformes compared to that recovered by analysis of a morphology-only dataset, the fossil taxon fell within Coraciiin both analyses (Clarke et al., 2009). Given the lack of wide consensus on the extant sister taxon of Coracioidea, Primobucco mcgrewi is at present best applied as a calibration for the divergence of Coracii versus all other listed taxa (Figure 5). Ongoing phylogenetic work on this sector of the avian tree should allow a more precise placement in the future.

Fossil Record of Coracii. Multiple near-contemporary records of Coracii are known in addition to Primobucco mcgrewi. Paracoracias occidentalis also occurs in the Green River Formation. Although the type horizon for this species was originally considered uncertain (Clarke et al., 2009), it has recently been placed in the Middle Eocene Laney Shale Member (Grande, 2013). Possible earlier records of Coracii have been referenced in the literature, but require further study. A partial tarsometatarsus from the early Eocene of Condé-en- 
Brie (France) was assigned to Primobucconidae indet. (Mayr et al., 2004). This specimen is not tightly constrained in age at present and could be contemporaneous with or slightly older than Primobucco mcgrewi based on placement of the fossil horizon within MP zone 8-9 (Schmitdt-Kittler, 1987). More complete material and refined dating is desirable before incorporating this record as a calibration point. A fossil from the Early Eocene (presumably London Clay) of England was referenced as a possible occurrence of Primobucconidae (M. Daniels, personal commun. in Mayr, 2005a), but details of this specimen have not yet been published. Many complete specimens of Coracii have been described from the Messel Formation of Germany ( 47 Ma, see Upupiformes / Bucerotiformes discussion for details of the age of this formation). Several species including Primobucco perneri, Primobucco frugilegus, and Eocoracias brachyptera, are each represented by multiple skeletons from Messel (Mayr et al., 2004). Late Eocene material from Quercy includes two species of stem roller, Geranopterus alatus, and Geranopterus milneedwardsi (Mayr and Mourer-Chauviré, 2000). Although Quercy specimens collected in the 19th century are from an uncertain stratigraphic horizon and may be Oligocene or Eocene in age, more recently collected specimens are estimated to be $\sim 35 \mathrm{Ma}$ in age (Mayr and MourerChauviré, 2000). Cryptornis antiquus represents another potential record from the Late Eocene (MP19) (Mayr and Mourer-Chauviré, 2004). A large gap separates these occurrences and the next oldest fossil, a tarsometatarsus assigned to Geranopterus bohemicus from the Early Miocene ( 17 Mya; Kempf et al., 1997) of the Czech Republic. Thus, the fossil record of Coracii is considered to be rather discontinuous (Figure 6).

It bears restating here that many specimens originally assigned to Primobucco or Primobucconidae are now considered to represent distantly related taxa (Houde and Olson, 1989, 1992; Mayr et al., 2004) that are not relevant to calibrating the divergence of Coracii. These include the stem parrot Cyrilavis olsoni (formerly "Primobucco" olsoni), the piciform Neanis schucherti, the stem mousebirds Uintornislucaris, Uintornismarionae, Botauroidesparvus and Eobucco brodkorbi, and "Neanis" kistneri (of uncertain affinities). Two other putative London Clay records of Primobucconidae, the partial tarsometatarsus holotype of Parvicuculus minor (Olson and Feduccia, 1979) and an unnamed partial tarsometatarsus (Harrison, 1982) are now con-

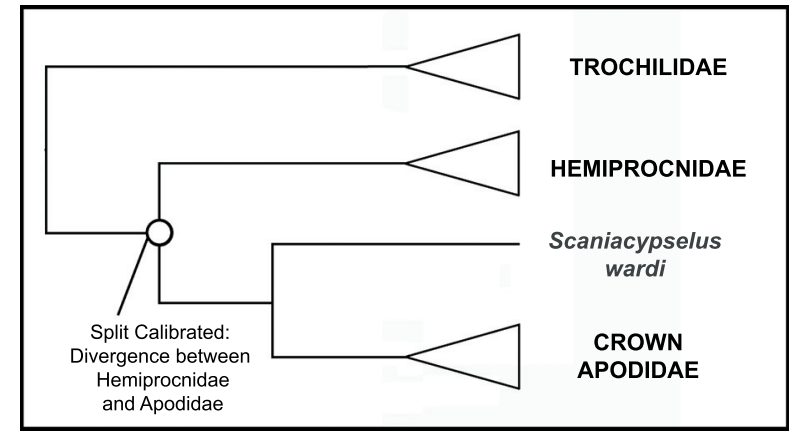

FIGURE 7. Phylogenetic tree showing position of Scaniacypselus wardi, illustrating the divergence calibrated by NHMUKA5430.

sidered to be unrelated to Coracii (Harrison, 1982; Mayr and Mourer-Chauviré, 2004).

Fossil Record of Related Clades. Given the general agreement that Coracii occupy some position within a clade including the contents of the traditional "Coraciiformes", we can achieve at least a general picture of the fossil record of potential sister taxa. The fossil Quasisyndactylus longibrachis from the Middle Eocene Messel Formation has been proposed as the sister taxon a clade uniting Alcedinidae, Todidae, Momotidae, and Meropidae (Mayr, 1998, 2005a). However, whether Meropidae belong to this clade is challenged by many analyses of molecular data. This in turn raises the question of whether this fossil may represent the sister taxon of just Alcedinidae, Todidae, and Momotidae or perhaps a larger clade also including Meropidae and several additional taxa. The oldest well-known representatives of Upupiformes are also from the Messel Formation (see below). Stem lineage todies first appear in the Late Eocene ( $35 \mathrm{Ma}$, Mourer-Chauviré, 1985), and stem lineage motmots first appear in the Early Oligocene (Olson, 1976). Thus, under most proposed phylogenetic hypotheses, the earliest fossil occurrence of the sister lineage to Coracii ranges from 5-15 Ma younger than Primobucco mcgrewi, indicating only a modest gap.

\section{APODIDAE (TRUE SWIFTS)}

Node Calibrated. Divergence between Apodidae and Hemiprocnidae.

Fossil Taxon. Scaniacypselus wardi (Harrison, 1984).

Specimen. NHMUKA5430 (Natural History Museum, London, UK): humerus, ulna, carpometacarpus, and alular phalanx.

Phylogenetic Justification. Phylogenetic analysis of morphological data (Mayr, 2003, 2005c) and 


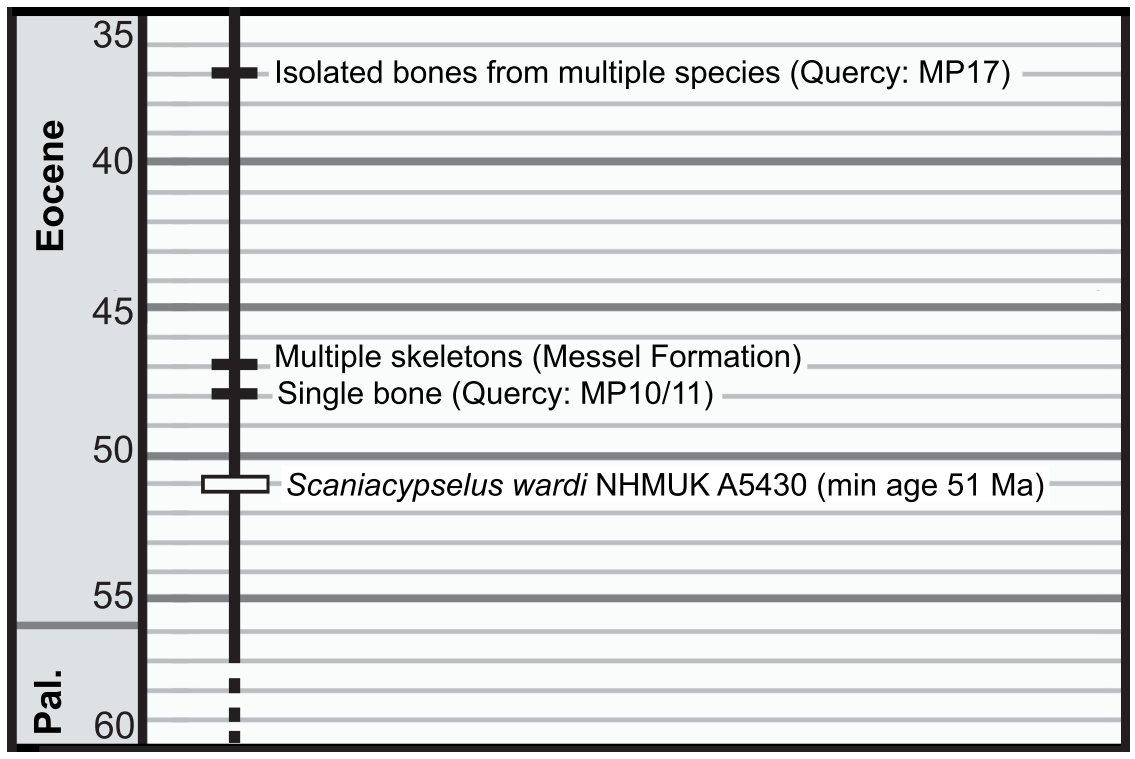

FIGURE 8. Stratigraphic distribution of fossil Pan-Apodidae in the Paleogene. The minimum possible age of the calibrating specimen NHMUK A5430 is presented, and midpoints of age ranges are shown for the ages of other Paleogene swift specimens.

combined morphological and molecular data (Ksepka et al., 2013).

Minimum Age. $51 \mathrm{Ma}$.

Age Justification. NHMUKA5430 was collected from Bed R6 of the Røsnæs Clay Formation of Ølst, Denmark (Harrison, 1984). Bed R6 is the uppermost division of the Røsnæs Clay Formation, and is overlain by Bed L1 of the Lillebælt Clay Formation (Heilmann-Clausen et al., 1985). Magnetostratigraphic work (Heilmann-Clausen et al., 2010) demonstrates that Bed L2 of the Lillebælt Clay spans part of Chron 22r, which constrains the age of the base of the Lillebælt Clay to $>49 \mathrm{Ma}$. Thiede et al. (1980) assigned the upper calcareous beds of the Røsnæs Clay Formation, including R5 and R6 to nannoplankton biozones NP11 and NP12. Biostratigraphy supports correlation of the Røsnæs Clay Formation to the European mammal reference biozone MP8 (Mlíkovsky, 1996), which suggests an age $>50 \mathrm{Ma}$ (Gradstein et al., 2004). A conservative minimum age of $51 \mathrm{Ma}$ is proposed, based specifically on the estimated age of the upper boundary of NP12, which is dated to $51 \mathrm{Ma}$ (Gradstein et al., 2012).

Phylogenetic Position of Apodidae. Nearly all phylogenetic analyses have strongly supported a sister group relationship between Apodidae and Hemiprocnidae, with Trochilidae forming the sister group to the Apodidae + Hemiprocnidae clade (Mayr, 2003, 2005c, 2010a; Cracraft et al., 2004; Barrowclough et al., 2006; Ericson et al., 2006; Hackett et al., 2008; Braun and Huddleston, 2009;
Nesbitt et al., 2011; Ksepka et al., 2013; though see Livezey and Zusi 2006, 2007) (Figure 7). Given the broad consensus that Apodidae and Hemiprocnidae are sister taxa, there is no conflict between morphological and molecular date to reconcile as pertains to the placement of Scaniacypselus wardi along the stem lineage leading to Apodidae.

Fossil Record of Pan-Apodidae. Swifts are known from a few good European specimens subsequent to their first appearance, though their fossil record is otherwise sparse (Figure 8). Scaniacypselus szarskii is known from multiple complete skeletons, some with intact feathering, from the Middle Eocene Messel Formation (Peters, 1985; Mayr and Peters, 1999). Additional fossils belonging to the true swift lineage include an isolated ulna of cf. Scaniacypselus from the Late Eocene of France (Mourer-Chauviré and Sigé, 2006), Procypseloides from the Eocene/Oligocene of France (Milne-Edwards, 1871; Mourer-Chauviré et al., 2004), and specimens from the Late Oligocene/ Early Miocene of Australia (Boles, 2001) and the Early and Middle Miocene of France (MilneEdwards, 1871; Ennouchi, 1930; Collins, 1976; Harrison, 1984; Mlíkovsky, 2002).

Fossil Record of Related Clades. Hemiprocnidae lack a fossil record. The classification of the Eocene fossil Eocypselus vincenti within Hemiprocnidae (Harrison, 1984; Dyke, 2001b) has been shown to be erroneous, and this taxon is now considered a basal representative of Pan-Apodi- 


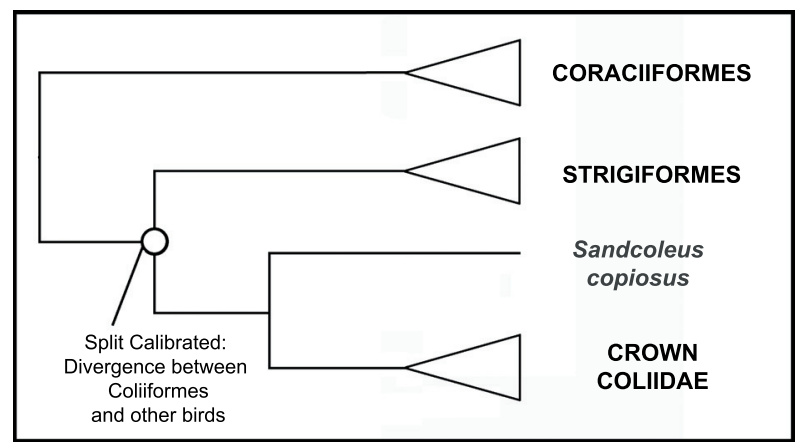

FIGURE 9. Phylogenetic tree showing position of Sandcoleus copiosus, illustrating the divergence calibrated by USNM 433912.

formes (Mayr, 2001a, 2010b; Ksepka et al., 2013). Pan-Trochilidae (stem hummingbirds) is represented in Middle Eocene, Late Eocene, and Early Oligocene deposits (Karhu, 1988, 1999; Mayr, 2004a, 2007; Bocheński and Bocheński, 2008; Louchart et al., 2008; Mayr and Micklich, 2008). Basal Pan-Apodiformes (taxa that diverged prior to the swift-hummingbird split) are also present in Eocene deposits in Europe and North America (Collins, 1976; Mourer-Chauviré, 1978, 1988a; Harrison and Walker, 1975; Mayr, 2010b; Ksepka et al., 2013). Because these stem swifts, stem hummingbirds, and basal pan-apodiforms were all small birds, it is plausible that the absence of Hemiprocnidae in the fossil record is due to geographical collecting biases. Hemiprocnidae occur today in Asia and Australasia, where relatively minimal fossil collecting effort has been expended compared to Europe and North America. Thus, the absence of Hemiprocnidae is not cause for extreme concern over the reliability of the calibration outlined here, though the small size of swifts in general implies a greater probability of a long gap at the base of the Apodidae-Hemiprocnidae divergence than might be expected for larger birds.

\section{COLIIFORMES (MOUSEBIRDS)}

Node Calibrated. Divergence between Coliiformes and their extant sister taxon (see below).

Fossil Taxon. Sandcoleus copiosus (Houde and Olson, 1992)

Specimen. USNM 433912, holotype of Sandcoleus copiosus: nearly complete skeleton collected in articulation from a calcareous nodule, now disarticulated by preparation.

Phylogenetic Justification. Phylogenetic analysis of morphological data (Mayr and Mourer-Chauviré, 2004; Zelenkov and Dyke, 2008; Ksepka and Clarke, 2009, 2010c). Analyses utilizing a compos- ite Sandcoleidae with scorings from Sandcoleus and several related taxa also support placing Sandcoleus copiosus along the mousebird stem lineage (Mayr and Mourer-Chauviré, 2004; Mayr, 2005d). No alternative hypothesis for a close relationship with an extant group other than mousebirds has been forwarded for Sandcoleus.

Minimum Age. 56.22 Ma.

Age Justification. USNM 433912 was collected from the Sand Coulee beds of the Willwood Formation in Clark Quadrangle, Wyoming (USA). These beds fall within the Plesiadapis cookei zone (biozone Cf-2) of the Clarkfordian North American Land Mammal Age (Houde and Olson, 1992). Biozone $\mathrm{Cf}-2$ is located above the base of Chron C24r. Although Chron C24r spans the PaleoceneEocene boundary, biozone Cf-2 occurs entirely within the Paleocene. Secord et al. (2006) obtained a weighted mean ${ }^{40} \mathrm{Ar} /{ }^{39} \mathrm{Ar}$ age of $59.00 \pm 0.30 \mathrm{Ma}$ for the Belt Ash, which occurs within the older Chron C26r. These authors used a cubic spline function to calibrate biozone boundaries to numerical dates, estimating the age of Cf- 2 as between $56.60 \mathrm{Ma}$ and $56.22 \mathrm{Ma}$. Together, the radiometric, paleomagnetic, and biostratigraphic data provide a tightly constrained estimate for the appearance of Sandcoleus copiosus.

Phylogenetic Position of Coliiformes. Higher level relationships of mousebirds remain uncertain, and they have been considered a "rogue" taxon (Wang et al., 2012). Coliiformes were recovered as the sister taxon of Strigiformes by the phylogenomic analysis of Hackett et al. (2008) (Figure 9). However, many alternate results have been reported, including sister group relationships between Coliiformes and Psittaciformes (Sorenson et al., 2003; Mayr and Clarke, 2003; Chubb, 2004), Trogoniformes (Espinosa de los Monteros, 2000; Livezey and Zusi, 2006, 2007), and Piciformes (Mayr et al., 2003). Other analyses did not fully resolve the position of Coliiformes but nonetheless resolved Strigiformes as distantly related to Coliiformes (Ericson et al., 2006; Brown et al., 2008). Placement of Sandcoleus copiosus is secure despite these conflicts, as each of the first three candidate sister taxa have been included as single outgroups in three separate analyses testing the placement of the fossil (Ksepka and Clarke, 2009) as have all four simultaneously (Ksepka and Clarke, 2010c). All of these analyses placed the fossil along the mousebird stem lineage, a position that is supported by multiple apomorphies (Mayr and Peters, 1999). Given the lack of consensus regarding the higher level affinities of mousebirds, 


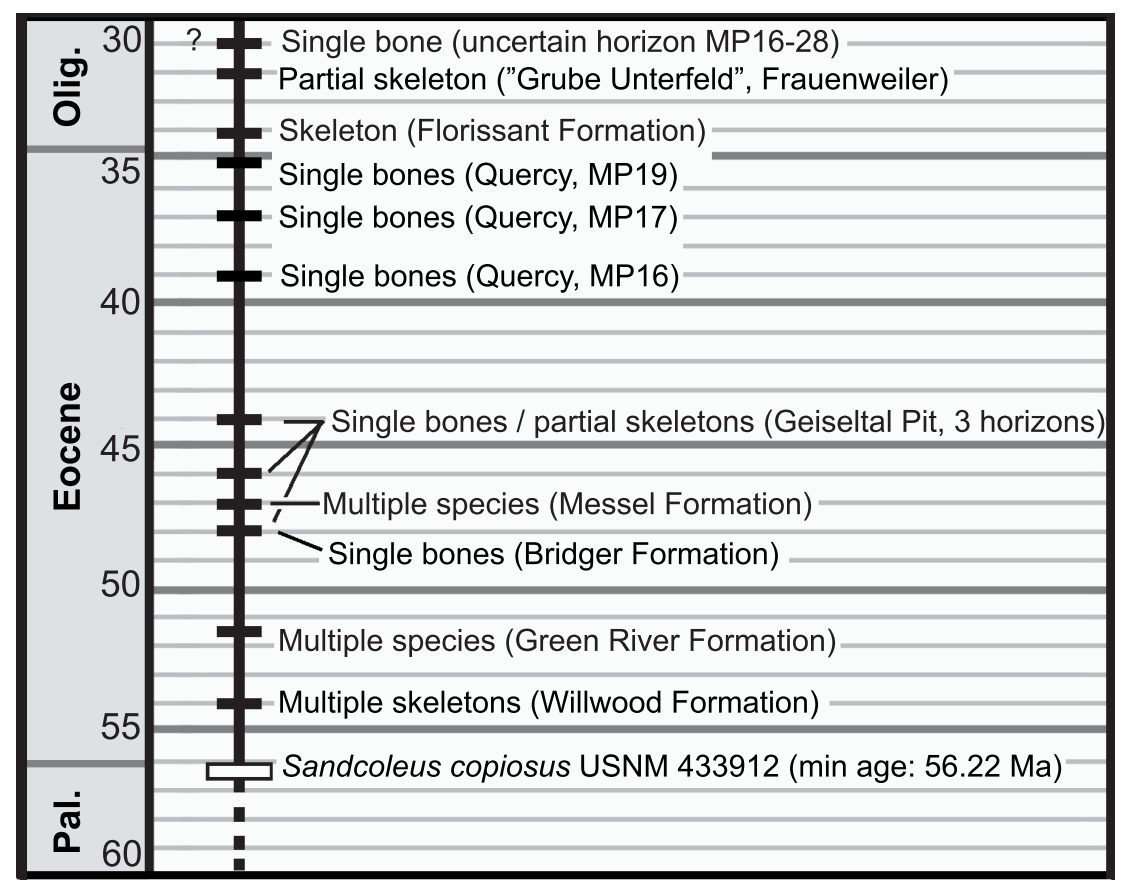

FIGURE 10. Stratigraphic distribution of fossil Coliiformes in the Paleogene. The minimum possible age of the calibrating specimen of Sandcoleus copiosus is presented, and midpoints of age ranges are shown for the ages of other Paleogene mousebird specimens.

we suggest the mousebird calibration is most appropriately utilized in analyses that sample a wide range of "higher land bird" taxa.

Fossil Record of Coliiformes. A relatively continuous temporal record is now recognized following the first appearance of Coliiformes, with fossils recovered from Early Eocene horizons in the Willwood Formation (early Wasatchian $~ 54 \mathrm{Ma}$; Houde and Olson, 1992), the Early Eocene Green River Formation ( $\sim 51.5 \mathrm{Ma}$; Houde and Olson, 1992; Ksepka and Clarke, 2010c), Middle Eocene Bridger Formation ( $48 \mathrm{Ma}$; Houde and Olson, 1992), Middle Eocene Messel Formation ( $\sim 7 \mathrm{Ma}$; Mayr and Peters, 1998; Peters, 1999; Mayr, 2000a), multiple Late Eocene horizons at Quercy (Mourer-Chauviré, 1988b) the latest Eocene Florissant Formation (Ksepka and Clarke, 2009), and the Early Oligocene Frauenweilerand Late Oligocene Enspel deposits of Germany (Mayr, 2000b, 2013b) (Figure 10). Mousebirds are also represented by a suite of fossil taxa from younger Neogene deposits.

Notably, the fossil record of mousebirds is concentrated to the Northern Hemisphere, whereas all six extant mousebird species are restricted to Africa. Although it is possible that older Southern Hemisphere fossils remain undiscovered, the placement of all phylogenetically constrained North American and European species outside the crown clade and the early Pliocene first appearances of mousebirds in Africa (Rich and Haarhoff, 1985) are consistent with origination in the Northern Hemisphere followed by a later Neogene dispersal into Africa. This scenario does not require substantial Southern Hemisphere gaps in the fossil record of the group.

Fossil Record of Related Clades. Due to the unresolved position of Coliiformes within Aves, it is premature to discuss in detail whether concordance exists between the fossil record of this group and its sister taxon. Most of the proposed candi-

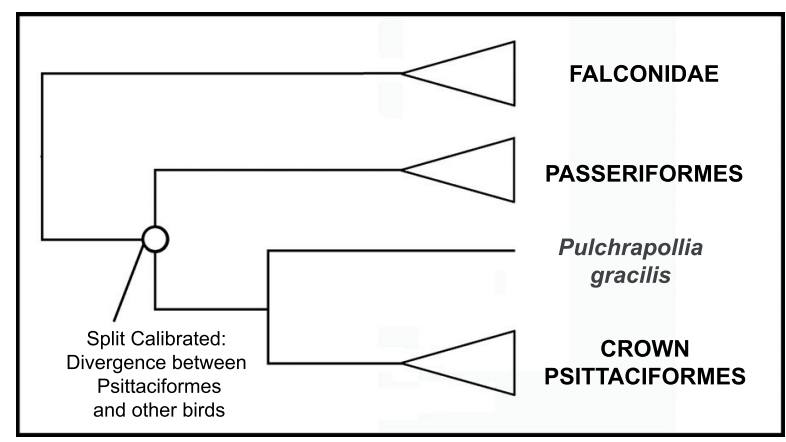

FIGURE 11. Phylogenetic tree showing position of Pulchrapollia gracilis, illustrating the divergence calibrated by NMH A6207. Placement of Pulchrapollia gracilis as a stem parrot is supported by multiple analyses (see text). 


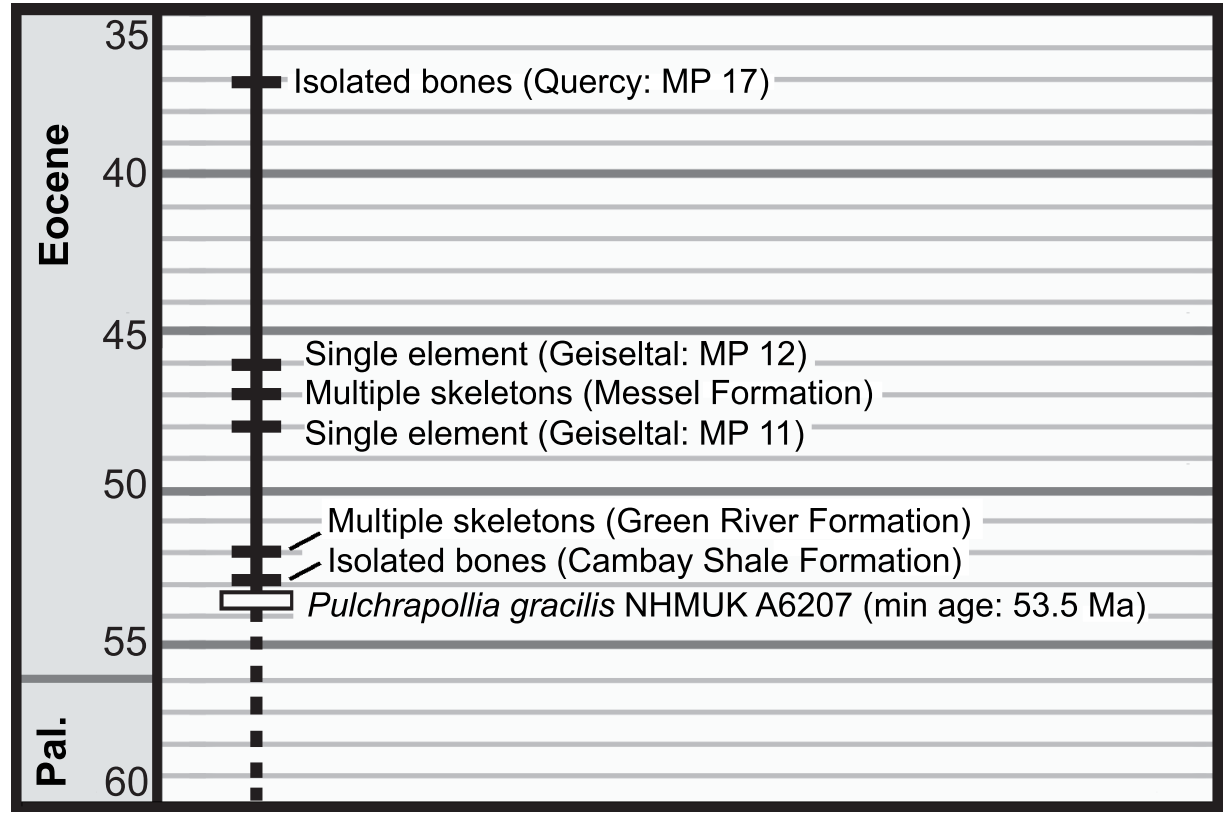

FIGURE 12. Stratigraphic distribution of fossil Pan-Psittaciformes in the Paleogene. The minimum possible age of the calibrating specimen NMH A6207 is presented, and midpoints of age ranges are shown for the ages of other Paleogene parrot specimens. Note that the London Clay Formation also contains multiple associated skeletons and isolated bones in addition to the holotype of Pulchrapollia gracilis that serves as a calibration point.

dates do show significant agreement, however, as Strigiformes also appear in the Paleocene (Rich and Bohaska, 1976) and Psittaciformes and Trogoniformes appear in the Early Eocene (Dyke and Cooper, 2000; Kristoffersen, 2002).

\section{PSITTACIFORMES (PARROTS)}

Node Calibrated. Divergence between Psittaciformes and Passeriformes (see below).

Fossil Taxon. Pulchrapollia gracilis (Dyke and Cooper, 2000).

Specimen. NHMUKA6207: partial skeleton including rostral tip of beak, quadrate, two vertebrae, partial scapula, partial humerus, complete ulna, partial carpometacarpus, phalanx I-1 and II-1, complete femur, partial tibiotarsus, complete tarsometatarsus, and nine pedal phalanges. A coracoid associated with the holotype is now considered to belong to another taxon (Mayr, 2001b).

Phylogenetic Justification. Phylogenetic analysis of morphological data (Dyke and Cooper, 2000; Mayr, 2005c), phylogenetic analysis of combined morphological and molecular data (Ksepka et al., 2011, Ksepka and Clarke, 2012).

Minimum Age. 53.5 Ma.

Age Justification. NMH A6207 was collected from the Walton Member (Division A2 of King, 1981) of the London Clay Formation at Walton-on-the-Naze, England. The Walton Member correlates to the upper part of Chron $\mathrm{C} 24 \mathrm{r}$ and to calcareous nannoplankton zone NP10-11 (Rhodes et al., 1999). Precise dating of Chron C24r is difficult and estimates vary depending on alternate cyclostratigraphic methods applied to extrapolate the length of the stratigraphic gap between the top of $\mathrm{C} 24 \mathrm{r}$ and horizons dated using radiometric means. Because a hard minimum calibration should be conservative, we selected the youngest estimate (inclusive of error) for the top of C24r (53.54+/-0.04) presented among the alternate estimates of Westerhold et al. (2007).

Phylogenetic Position of Psittaciformes. Consensus is building for a sister group relationship between Psittaciformes and Passeriformes (Psittacopasserae of Suh et al., 2011) (Figure 11). The phylogenomic analysis of Hackett et al. (2008) supported this pairing, as did most analyses of a 30 nuclear loci dataset (Wang et al., 2012) and analysis of retroposon insertions (Suh et al., 2011). A trichotomy including Psittaciformes, Passeriformes, and Falconidae was recovered by the nuclear gene study of Ericson et al. (2006). However, mitochondrial studies have placed Psittaciformes near the base of Neoaves (Pratt et al., 2009) or as sister taxon to Strigiformes (Pacheco et al., 2011). Morphological analyses have supported a sister group relationship between Coliiformes and Psittaciformes (Mayr and Clarke, 2003), near the base of a 
"higher land bird" assemblage (Livezey and Zusi, 2006,2007 ), or, with a more limited outgroup sampling, as sister group to Passeriformes (Ksepka et al., 2011). Despite any uncertainty over the higher level relationship of Psittaciformes, Pulchrapollia gracilis shares unique characters with extant parrots (Dyke and Cooper, 2001; Mayr, 2002) and remains in the same position relative to crown Psittaciformes even when disparate groups such as Musophagidae, Coliiformes, and Passeriformes are recovered as the extant sister taxon of Psittaciformes (Dyke and Cooper, 2000, Ksepka et al., 2011; Mayr, 2011). Thus, we consider the placement of Pulchrapollia gracilis as a stem parrot to be secure.

Fossil Record of Pan-Psittaciformes. A substantial record of Eocene stem parrots is now known (Figure 12). Several partial skeletons of unnamed fossil taxa have been reported from the London Clay (Mayr and Daniels, 1998). These taxa are interpreted as more closely related to crown clade Psittaciformes than Pulchrapollia gracilis (Mayr, 2002). Slightly younger but more complete records of stem Psittaciformes are provided by Cyrilavisolsoni and Cyrilavis colburnorum, known from several complete and partial skeletons from the Fossil Butte Member of the Green River Formation (51.66 $\pm 0.09 \mathrm{Ma}$ : see above discussion concerning the age of the Fossil Butte Member). An even larger collection of skeletons representing multiple species is known from the Messel Formation ( 47 Ma) (Mayr and Peters, 1998). Additional Middle Eocene records have been reported from Geiseltal (Mayr, 2000a). Late Eocene records of Psittaciformes include isolated elements assigned to the Quercypsittidae (Mourer-Chauviré, 1992). Vastanavidae, a group of that may also represent stem parrots, are known from isolated elements from the Early Eocene of India (Mayr et al., 2010).

Two putative stem parrots from the Early Eocene Fur Formation are contemporary with, or slightly older than, Pulchrapollia gracilis, but do not meet all of the criteria for inclusion as calibration points laid out above. These fossils were described as Mopsitta tanta and Pseudasturidae incertae sedis (Kristofferson, 2002; Waterhouse et al., 2008). Both taxa are represented solely by a humerus, and the psittaciform affinities of Mopsitta tanta are now considered doubtful given a lack of unambiguous synapomorphies supporting a relationship with parrots and recognition of similarities to the stem ibis Rhynchaeites (Mayr and Bertelli, 2011). Regardless of phylogenetic status, it is uncertain whether the age of these fossils is greater than that of Pulchrapollia gracilis. Numerous volcanic ash layers occur in the Fur Formation, and these are designated by a series of numbers, ranging from +140 for the highest ash in the formation to -39 for the lowest. Two radioisotopic dates have been reported from these ashes: a date of $54.04+/-0.14 \mathrm{Ma}$ from layer +19 and a date of $54.52+/-0.05 \mathrm{Ma}$ from layer -17 (Chambers et al., 2003). Unfortunately, the horizon from which these putative fossil parrots were recovered was not reported, so whether these dates provide a minimum age, maximum age, or together bound the age of the fossils cannot be determined. Given their incomplete nature and controversial phylogenetic status, we recommend against utilizing the Fur fossils from divergence studies pending further evidence. However, we note the older of the two radiometrically dated layers is only $\sim 1 \mathrm{Ma}$ older than the hard minimum age of Pulchrapollia gracilis and so the potential increase in calibration age is slight.

A partial mandible from the Late Cretaceous Lance Formation was attributed to a parrot by Stidham (1998), though this record has remained controversial (Dyke and Mayr, 1999; Stidham, 1999). Following the guidelines above, we do not consider this fossil as a calibration point due to its incomplete nature and the lack of phylogenetic analysis supporting its referral.

Fossil Record of Related Clades. As with Coliiformes, it is unlikely that further work on the higherlevel affinities of Psittaciformes will significantly impact the calibration age. The oldest reported record of Passeriformes, the probable sister taxon of Psittaciformes, is also from the Early Eocene (Boles, 1995). Paleocene fossil records of Passeriformes are otherwise restricted to the Oligocene. However, if the extinct Zygodactylidae represent the closest fossil relatives of Passeriformes as proposed by Mayr (2004b, 2008b), the record of the stem lineage leading to Passeriformes would also include many additional Eocene and Oligocene

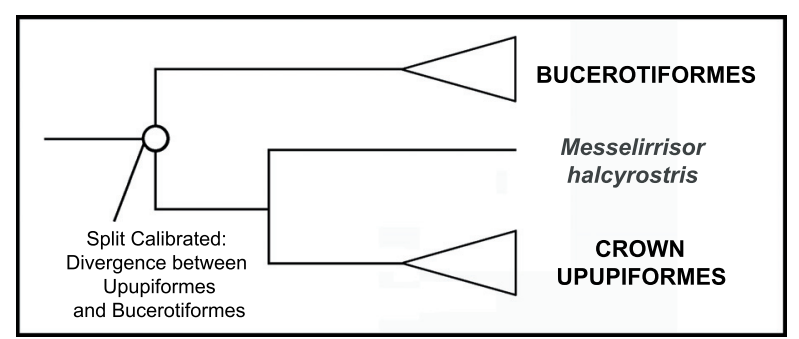

FIGURE 13. Phylogenetic tree showing position of Messelirrisor halcyrostris, illustrating the divergence calibrated by SMF-ME 1883a+b. 


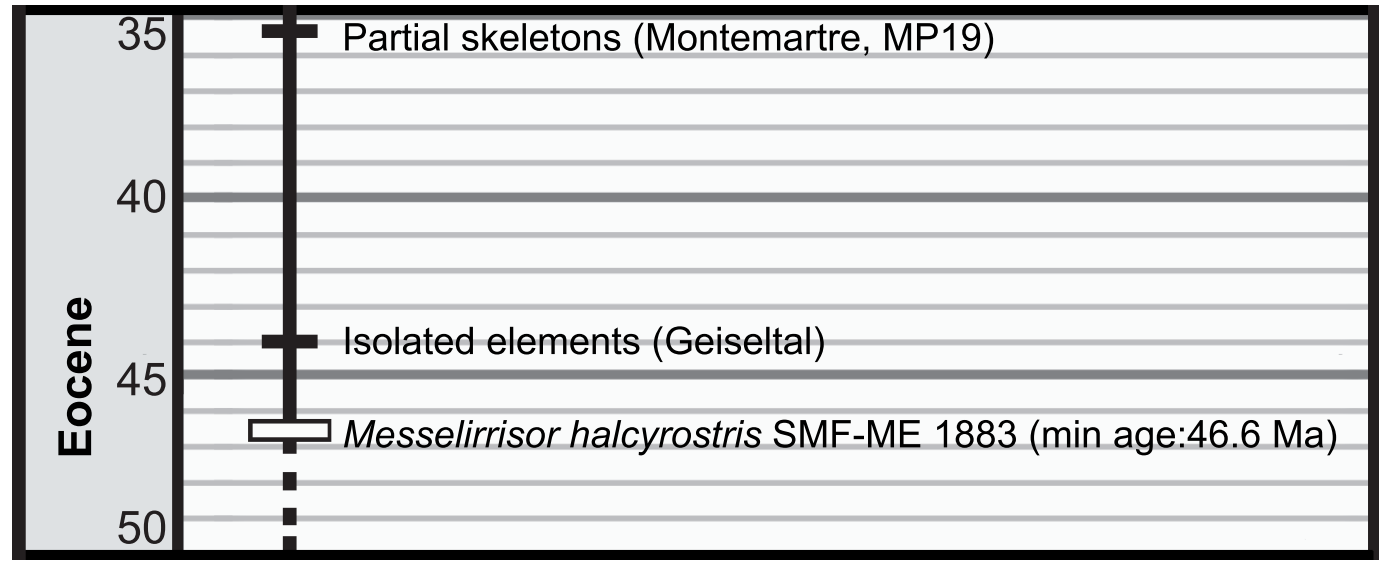

FIGURE 14. Stratigraphic distribution of fossil Upupiformes in the Paleogene. The minimum possible age of the calibrating specimen SMF-ME 1883a+b is presented, and midpoints of age ranges are shown for the ages of other Paleogene Upupiformes. The fossil record of Upupiformes is probably more complete than implied by the figure as several important specimens may belong to this clade await evaluation (see text).

records from Europe and North America. The oldest records of Coliiformes and Strigiformes are both from the Late Paleocene (Houde and Olson, 1992; Rich and Bohaska, 1976).

\section{STEM UPUPIFORMES (HOOPOES AND WOOD HOOPOES)}

Node Calibrated. Divergence of Upupiformes from Bucerotiformes.

Fossil Taxon. Messelirrisor halcyrostris (Mayr, 1998).

Specimen. SMF-ME 1883a+b (Forschungsinstitut Senckenberg, Frankfurt, Germany): complete skeleton. Additional complete skeletons of Messelirrisor halcyrostris and closely related species are also known from the same locality as this specimen (Mayr, 1998), which we chose for its completeness and preservation of key morphological features.

Phylogenetic Justification. Phylogenetic analysis of morphological data (Mayr, 2006).

Minimum Age. 46.6 Ma.

Age Justification. SMF-ME $1883 a+b$ was collected from the Messel Pit. A maximum age for the fossiliferous deposits of the Messel Formation is provided by a $47.8 \pm 0.2 \mathrm{Ma}{ }^{40} \mathrm{Ar} / 39 \mathrm{Ar}$ age obtained from the basalt chimney below Lake Messel (Mertz et al., 2004). This date provides a maximum age for Lake Messel itself, but a minimum age for the fossil must take into account time elapsed between the cooling of the basalt and the deposition of the fossiliferous layers which occur higher in the section. Lacustrine sediments are estimated to have filled in the maar lake that formed above this basalt chimney over a span of approximately $1 \mathrm{Ma}$ (Mertz et al., 2004). Account- ing for sedimentation rate, the layers yielding avian fossils (including SMF-ME 1883a+b) are most likely $\sim 47 \mathrm{Ma}$ in age (Mertz et al., 2004; Franzen, 2005). When both the error range associated with the dating of the basalt $( \pm 0.2 \mathrm{Ma})$ and the estimate of time spanned between this date and deposition of the fossil (1 Ma) are incorporated, the hard minimum age for the fossil is $46.6 \mathrm{Ma}$.

Phylogenetic Position of Upupiformes. A sister group relationship between Upupiformes and Bucerotiformes (hornbills) is well supported by morphological (Burton, 1984; Mayr, 1998, 2006; Livezey and Zusi, 2006, 2007) and molecular data (Johansson et al., 2001; Cracraft et al., 2004; Ericson et al., 2006; Hackett et al., 2008) (Figure 13). Thus, there is no conflict between morphological and molecular data that may affect the placement of Messelirrisor halcyrostris.

Fossil Record of Upupiformes. Messelirrisoridae are well-represented in the Messel Formation. Besides Messelirrisor halcyrostris, two additional species (M. parvus and $M$. grandis) are also known from multiple largely complete specimens, some with soft-tissue preservation (Mayr, 1998, 2006).

Potential older records of stem lineage Upupiformes have been reported. Less complete specimens from the Early Eocene London Clay Formation have been referred to the Messelirrisoridae (Mayr, 1998). Following the guidelines above, we do not include these specimens as a recommended calibration point pending phylogenetic analyses confirming their identity. Younger and less complete records of stem Upupiformes are known from slightly younger ( $44 \mathrm{Ma})$ Middle Eocene deposits at Geiseltal. Two partial skeletons of the 
taxon Laurillardia from the Late Eocene of France (Milne-Edwards, 1871; Flot, 1891) are also recognized as stem Upupiformes (Mayr, 1998). Miocene specimens assigned to stem members of Phoeniculidae (wood hoopoes) have been described from the Early Miocene of Germany and France (Ballman, 1969; Mlíkovský and Göhlich, 2000).

The fossil record of Upupiformes is probably more complete than implied by Figure 14, as several important specimens that may belong to this clade await evaluation. Mayr (2009) considered it likely that a complete skeleton from the Early Eocene Green River Formation figured by Grande (1984, p. 212) represents a member of the Upupiformes + Bucerotiformes clade. It is possible that this fossil may eventually justify a revision of the minimum calibration age for the UpupiformesBucerotiformes split. However, it is best to await phylogenetic appraisal of the fossil, which could potentially occupy a more basal position (e.g., along the stem leading to the clade Upupiformes + Bucerotiformes) or belong to a distantly related clade (Grande, 1984, noted a resemblance to kingfishers). Mayr (2009) also mentioned the occurrence of upupiform specimens from the Early Oligocene of France, which currently remain in private collections.

Fossil Record of Related Clades. Bucerotiformes have a very sparse fossil record, comprising only two pre-Holocene species: Bucorvus brailloni from the Middle Miocene (Brunet, 1971) and Euroceros bulgaricus from the Late Miocene (Boev and Kovachev, 2007). This poor record is potentially related to sparse sampling of the fossil record within the bounds of the clade's modern geographical distribution (Africa, Asia, and Australasia).

\section{DISCUSSION}

Fossil data must play a critical role in any attempt to resolve the timing of key divergences in the crown radiation of birds. Only recently has major effort begun to be devoted to including fossil avian taxa into phylogenetic analyses. As these efforts proceed, we anticipate a large increase in the number of vetted fossil calibrations for birds.

\section{ACKNOWLEDGMENTS}

This research was supported by the National Evolutionary Synthesis Center (NSF EF-0905606 and EF-0423641). We thank Estelle Bourdon and an annonymous reviewer for helpful comments.

\section{REFERENCES}

Averianov, A. and Sues, H.D. 2012. Correlation of Late Cretaceous continental vertebrate assemblages in Middle and Central Asia. Journal of Stratigraphy, 36:462-485.

Baker, A.J., Pereira, S.L., and Paton, T.A. 2007. Phylogenetic relationships and divergence times of Charadriiformes genera: multigene evidence for the Cretaceous origin of at least 14 clades of shorebirds. Biology Letters, 3:205-209.

Ballmann, P. 1969. Die Vögel aus der altburdigalen Spaltenfüllung von Wintershof (West) bei Eichstätt in Bayern. Zitteliana, 1:5-61.

Barrowclough, G.F., Groth, J.G., and Mertz, L.A. 2006. The RAG-1 exon in the avian order Caprimulgiformes: Phylogeny, heterozygosity, and base composition. Molecular Phylogenetics and Evolution, 41:238-248.

Benson, R.D. 1996. Presbyornis isoni and other Late Paleocene birds from North Dakota. Smithsonian Contributions to Paleobiology, 89:253-260.

Benton, M.J., Donoghue, P.C.J., and Asher, R.J. 2009. Calibrating and constraining molecular clocks, p. 3586. In Hedges, S.B. and Kumar, S. (eds.), The Timetree of Life. Oxford University Press, Oxford.

Bocheński, Z. and Bocheński, Z.M. 2008. An Old World hummingbird from the Oligocene: a new fossil from Polish Carpathians. Journal of Ornithology, 149:211216.

Boev, Z. and Kovachev, D. 2007. Eurocerosbulgaricus gen. nov., sp. nov. from Hadzhidimovo (SW Bulgaria) (Late Miocene-the first European record of hornbills (Aves: Coraciiformes). Geobios, 40:39-49.

Boles, W.E. 1995. The world's earliest songbird (Aves: Passeriformes). Nature, 374:21-22.

Boles, W.E. 2001. A swiftlet (Apodidae:Collocaliini) from the Oligo-Miocene of Riversleigh, northwestern Queensland. Memoir of the Association of Australasian Palaeontologists, 25:45-52.

Bourdon, E., Mourer-Chauviré, C., Amaghzaz, M., and Bouya, B. 2008. New specimens of Lithoptila abdounensis (Aves, Prophaethontidae) from the Lower Paleogene of Morocco. Journal of Vertebrate Paleontology, 28:751-761.

Braun, M.J. and Huddleston, C.J. 2009. A molecular phylogenetic survey of caprimulgiform nightbirds illustrates the utility of non-coding sequences. Molecular Phylogenetics and Evolution, 53:948-960.

Brodkorb, P. 1970. An Eocene Puffbird from Wyoming. Contributions to Geology, 9:13-15.

Brown, J., Rest, J., Garcia-Moreno, J., Sorenson, M., and Mindell, D. 2008. Strong mitochondrial DNA support for a Cretaceous origin of modern avian lineages. BMC Biology, 6:6.

Brunet, J. 1971. Oiseaux miocènes de Beni-Mellal (Maroc); un complément à leur étude. Notes et Mémoires du Service Géologique du Maroc, 31:109111. 
Burton, P. 1984. Anatomy and evolution of the feeding apparatus in the avian orders Coraciiformes and Piciformes. Bulletin of the British Museum (Natural History) Zoology Series, 47:331-443.

Case, J.A., Martin, J.E., Chaney, D.S., Reguero, M., Marenssi, S.A., Santillana, S.M., and Woodburne, M.O. 2000. The first duck-billed dinosaur (Family Hadrosauridae) from Antarctica. Journal of Vertebrate Paleontology, 20:612-614.

Chambers, L.M., Pringle, M., Fitton, G., Larsen, L.M., Pedersen, A.K., and Parrish, R. 2003. Recalibration of the Palaeocene-Eocene boundary (P-E) using high precision $\mathrm{U}-\mathrm{Pb}$ and $\mathrm{Ar}-\mathrm{Ar}$ isotopic dating. Geophysical Research Abstracts, EGS-AGU-EUG Joint Assembly, Nice, 6th-11th April 2003:9681-9682.

Cheneval, J. 1995. A fossil shearwater (Aves: Procellariiformes) from the Upper Oligocene of France and the Lower Miocene of Germany. Courier Forschungsinstitut Senckenberg, 181:187-198.

Chubb, A.L. 2004. New nuclear evidence for the oldest divergences among neognath birds: phylogenetic utility of ZENK (I). Molecular Phylogenetics and Evolution, 30:140-151.

Clarke, J.A. and Norell, M.A. 2004. New avialan remains and a review of the Late Cretaceous Nemegt Formation of Mongolia. American Museum Novitates, 3447:1-2.

Clarke, J.A., Olivero, E.B., and Puerta, P. 2003. Description of the earliest fossil penguin from South America and first Paleogene vertebrate locality of Tierra del Fuego, Argentina. American Museum Novitates, 3423:1-18.

Clarke, J.T., Warnock, R.C.M., and Donoghue, P.C.J. 2011. Establishing a time-scale for plant evolution. New Phytologist, 192:266-301.

Clarke, J.A., Ksepka, D.T., Smith, N.A., and Norell, M.A. 2009. Combined phylogenetic analysis of a new North American fossil species confirms widespread Eocene distribution for stem rollers (Aves, Coracii). Zoological Journal of the Linnean Society, 157:586611.

Clarke, J.A., Tambussi, C.P., Noriego, J.I., Erickson, G.M., and Ketcham, R.A. 2005. Definitive fossil evidence for the extant avian radiation in the Cretaceous. Nature, 433:305-308.

Clarke, J.A., Ksepka, D.T., Stucchi, M., Urbina, M., Giannini, N., Bertelli, S., Narváez, Y., and Boyd, C.A. 2007. Paleogene equatorial penguins challenge the proposed relationship between biogeography, diversity, and Cenozoic climate change. Proceedings of the National Academy of Sciences, 104:1154511550.

Clarke, J.A., Ksepka, D.T., Salas-Gismondi, R., Altamirano, A.J., Shawkey, M.D., D'Alba, L., Vinther, J., DeVries, T.J., and Baby, P. 2010. Fossil evidence for evolution of the shape and color of penguin feathers. Science, 330:954-957.
Collins, C.T. 1976. Two new species of Aegialornis from France, with comments on the ordinal affinities of the Aegialornithidae. Smithsonian Contributions to Paleobiology, 27:121-127.

Cooper, A. and Penny, D. 1997. Mass survival of birds across the Cretaceous-Tertiary boundary: molecular evidence. Science, 275:1109-1113.

Cooper, R.A. 2004. The New Zealand Geological Timescale. Institute of Geological and Nuclear Sciences, Lower Hutt.

Cracraft, J.L. 1970. A new species of Telmabates (Phoenicopteriformes) from the lower Eocene of Patagonia. The Condor, 72:479-480.

Cracraft, J.F., Barker, K., Braun, J., Harshman, J., Dyke, G.J., Feinstein, J., Stanley, S., Cibois, A., Schikler, P., Beresford, P., García-Moreno, J., Sorenson, M.D., Yuri, T., and Mindell, D.P. 2004. Phylogenetic relationships among modern birds (Neornithes): towards an avian tree of life, p. 468-489. In Cracraft, J. and Donoghue, M.J. (eds.), Assembling the Tree of Life. Oxford University Press, New York.

Crame, J., Francis, J., Cantrill, D., and Pirrie, D. 2004. Maastrichtian stratigraphy of Antarctica. Cretaceous Research, 25:411-423.

Crame, J., McArthur, J., Pirrie, D., and Riding, J. 1999. Strontium isotope correlation of the basal Maastrichtian Stage in Antarctica to the European and US biostratigraphic schemes. Journal of the Geological Society, 156:957-964.

De Pietri, V.L., Berger, J.-P., Pirkenseer, C., Scherler, L., and Mayr, G. 2010. New skeleton from the early Oligocene of Germany indicates a stem-group position of diomedeoidid birds. Acta Palaeontologica Polonica, 55:343-344.

Donoghue, P.C.J. and Benton, M.J. 2007. Rocks and clocks: calibrating the Tree of Life using fossils and molecules. Trends in Ecology and Evolution, 22:424431.

Drummond, A.J. and Rambaut, A. 2007. BEAST: Bayesian evolutionary analysis by sampling trees. BMC Evolutionary Biology, 7:214.

Drummond, A.J., Ho, S.Y.W., Phillips, M.J., and Rambaut, A. 2006. Relaxed phylogenetics and dating with confidence. PLoS Biology, 4:e88.

Dyke, G.J. 2001a. The Fossil Waterfowl (Aves: Anseriformes) from the Eocene of England. American Museum Novitates, 3354:1-15.

Dyke, G.J. 2001b. A primitive swift from the London Clay and the relationships of fossil apodiform birds. Journal of Vertebrate Paleontology, 21:195-200.

Dyke, G.J. and Cooper, J.H. 2000. A new psittaciform bird from the London Clay (Lower Eocene) of England. Palaeontology, 43:271-285.

Dyke, G.J. and Mayr, G. 1999. Did parrots exist in the Cretaceous period? Nature 339:317-318.

Ennouchi, E. 1930. Contribution à l'étude de la faune du Tortonien de La Grive-Saint-Alban (Isère). Presses Modernes, Paris. 
Ericson, P.G.P. 1997. Systematic relationships of the Paleogene family Presbyornithidae (Aves: Anseriformes). Zoological Journal of the Linnean Society, 121:429-483.

Ericson, P.G.P. 2000. Systematic revision, skeletal anatomy, and paleoecology of the New World early Tertiary Presbyornithidae (Aves, Anseriformes). PaleoBios, 20:1-23.

Ericson, P.G.P., Anderson, C.L., Britton, T., Elzanowski, A., Johansson, U.S., Källersjö, M., Ohlson, J.I., Parsons, T.J., Zuccon, D., and Mayr, G. 2006. Diversification of Neoaves: integration of molecular sequence data and fossils. Biology Letters, 4:543-547.

Espinosa de los Monteros, A. 2000. Higher-level phylogeny of Trogoniformes. Molecular Phylogenetics and Evolution, 14:20-34.

Fain, M.G. and Houde, P. 2004. Parallel radiations in the primary clades of birds. Evolution, 58:2558-2573.

Feduccia, A. and McGrew, P.O. 1974. A flamingo-like wader from the Eocene of Wyoming. Contributions to Geology (University of Wyoming), 113:49-61.

Feduccia, A. and McPherson, A.B. 1993. A petrel-like bird from the late Eocene of Louisiana: Earliest record for the Procellariiformes. Proceedings of the Biological Society of Washington, 106:749-751.

Fischer, K. 1985. Ein albatrosartiger Vogel (Diomedeoidesminimus nov. gen., nov. sp., Diomedeoididae nov. fam., Procellariiformes) aus dem Mitteloligozän bei Leipzig (DDR). Mitteilungen aus dem Zoologischen Museum in Berlin, 61:113-118.

Flot, M. 1891. Description de deux oiseaux nouveaux du Gypse Parisien. Mémoires de la Société Géologique de France, Paléontologie, 7:1-10.

Fordyce, R.E. and Jones, C.M. 1990. Penguin history and new fossil material from New Zealand, p. 419446. In Davis, L.S. and Darby, J.T. (eds.), Penguin Biology. Academic Press, San Diego.

Fordyce, R.E. and Thomas, D.B. 2011. Kaiika maxwelli, a new Early Eocene archaic penguin (Sphenisciformes, Aves) from Waihao Valley, South Canterbury, New Zealand. New Zealand Journal of Geology and Geophysics, 54:43-51.

Franzen, J.F. 2005. The implications of the numerical dating of the Messel fossil deposit (Eocene, Germany) for mammalian biochronology. Annales de Paléontologie, 91:329-335.

Gradstein, F.M., Ogg, J.G., Schmitz, M., and Ogg, G. 2012. Geological Time Scale 2012. Elsevier Science and Technology, Amsterdam.

Gradstein, F., Ogg, J., and Smith, A. 2004. A Geologic Time Scale 2004. University of Cambridge Press, Cambridge, England.

Grande, L. 1984. Paleontology of the Green River Formation, with a review of the fish fauna. Bulletin of the Geological Survey of Wyoming, 63:1-333.

Grande, L. 2013. The Lost World of Fossil Lake: Snapshots from Deep Time. University of Chicago Press, Chicago.
Grande, L. and Buchheim, H.P. 1994. Paleontological and sedimentological variation in early Eocene Fossil Lake. Contributions to Geology, 30:33-56.

Hackett, S.J., Kimball, R.T., Reddy, S., Bowie, R.C.K., Braun, E.L., Braun, M.J., Chojnowski, J.L., Cox, W.A., Han, K.-L., Harshman, J., Huddleston, C.J., Marks, B.D., Miglia, K.J., Moore, W.S., Sheldon, F.H., Steadman, D.W., Witt, C.C., and Yuri, T. 2008. A phylogenomic study of birds reveals their evolutionary history. Science, 320:1763-1768.

Harrison, C.J.O. 1982. The earliest parrot: a new species from the British Eocene. Ibis, 124:203-210.

Harrison, C.J.O. 1984. A revision of the fossil swifts (Vertebrata, Aves, suborder Apodi), with descriptions of three new genera and two new species. Mededelingen van de Werkgroep voor Tertiaire en Kwartaire Geologie, 21:157-177.

Harrison, C.J.O. and Walker, C.A. 1975. A new swift from the Lower Eocene of Britain. Ibis, 117:162-164.

Harrison, G.L., McLenachan, P.A., Phillips, M.J., Slack, K.E., Cooper, A., and Penny, D. 2004. Four new avian mitochondrial genomes help get to basic evolutionary questions in the Late Cretaceous. Molecular Biology and Evolution, 21:974-983.

Harshman, J. 1994. Reweaving the tapestry: what can we learn from Sibley and Ahlquist (1990)? Auk, 111:377-388.

Hedges, S., Parker, P., Sibley, C., and Kumar, S. 1996. Continental breakup and the ordinal diversification of birds and mammals. Nature, 381:226-229.

Heilmann-Clausen, C., Beyer, C., and Snowball, I. 2010. Stratigraphy and paleoenvironment of the Danish Eocene Azolla event. Geophysical Research Abstracts, 12:EGU2010-12095.

Heilmann-Clausen, C., Nielsen, O.B., and Gersner, F. 1985. Lithostratigraphy and depositional environments in the upper Paleocene and Eocene of Denmark. Bulletin of the Geological Society of Denmark, 33:287-323.

Ho, S.Y.W. and Phillips, M.J. 2009. Accounting for calibration uncertainty in phylogenetic estimation of evolutionary divergence times. Systematic Biology, 58:367-380.

Hope, S. 2002. The Mesozoic Radiation of Neornithes, p. 339-388. In Chiappe, L.M. and Witmer, L.M. (eds.), Mesozoic Birds: Above the Heads of Dinosaurs. University of California Press, Berkeley.

Houde, P. and Olson, S. 1989. Small arboreal non-passerine birds from the early Tertiary of western North America, p. 2030-2036. In Ouellet, H. (ed.), Acta XIX Congressus Internationalis Ornithologici. University of Ottawa Press, Ottawa.

Houde, P. and Olson, S.L. 1992. A radiation of coly-like birds from the Eocene of North America (Aves: Sandcoleiformes new order). Papers in Avian Paleontology honoring Pierce Brodkorb. Natural History Museum of Los Angeles County, Science Series, $36: 137-160$. 
Howard, H. 1955. A new wading bird from the Eocene of Patagonia. American Museum Novitates, 1710: 1-26.

Inoue, J., Donoghue, P.C.J., and Yang, Z. 2010. The impact of the representation of fossil calibrations on Bayesian estimation of species divergence times. Systematic Biology, 59:74-89.

Jadwiszczak, P. 2006a. Eocene penguins of Seymour Island, Antarctica: Taxonomy. Polish Polar Research, 27:3-62.

Jadwiszczak, P. 2006b. Eocene penguins of Seymour Island, Antarctica: the earliest record, taxonomic problems and some evolutionary considerations. Polish Polar Research, 27:287-302.

Jadwiszczak, P., Acosta Hospitaleche, C., and Reguero, M. 2013. Redescription of Crossvallia unienwillia: the only Paleocene Antarctic penguin. Ameghiniana, 50: 545-553.

Johansson, U.S., Parsons, T.J., Irestedt, M., and Ericson, P.G.P. 2001. Clades within the 'higher land birds', evaluated by nuclear DNA sequences. Journal of Zoological Systematics and Evolutionary Research, 39:37-51.

Karhu, A. 1988. Novoye semeystvo strizheobraznykh iz paleogena Yevropy. Palaeontologicheskii Zhurnal, 3:78-88.

Karhu, A. 1999. A new genus and species of the family Jungornithidae (Apodiformes) from the Late Eocene of the Northern Caucasus, with comments on the ancestry of hummingbirds. Smithsonian Contributions to Paleobiology, 89:207-216.

Kempf, O., Bolliger, T., Kälin, D., Engesser, B., and Matter, A. 1997. New magnetostratigraphic calibration of Early to Middle Miocene mammal biozones of the North Alpine foreland basin. Mémoires et Travaux de l'Ecole Pratique des Hautes Etudes, Institut de Montpellier, 21:547-561.

King, C. 1981. The stratigraphy of the London Clay and associated deposits. Tertiary Research, Special Paper 6:1-158.

Kristofferson, A. 2002. The avian diversity in the latest Palaeocene - earliest Eocene Fur Formation, Denmark: a synopsis. University of Copenhagen, Copenhagen.

Kristoffersen, A.V. 2002. An early Paleogene trogon (Aves: Trogoniformes) from the Fur Formation, Denmark. Journal of Vertebrate Paleontology, 22:661666.

Ksepka, D.T. 2009. Broken gears in the avian molecular clock: new phylogenetic analyses support stem galliform status for Gallinuloides wyomingensis and rallid affinities for Amitabha urbsinterdictensis. Cladistics 25:173-197.

Ksepka, D.T. and Clarke, J.A. 2009. Affinities of Palaeospiza bella and the phylogeny and biogeography of mousebirds (Coliiformes). Auk, 126:245-259.
Ksepka, D.T. and Clarke, J.A. 2010a. The basal penguin (Aves: Sphenisciformes) Perudyptes devriesi and a phylogenetic evaluation of the penguin fossil record. Bulletin of the American Museum of Natural History, 337:1-77.

Ksepka, D.T. and Clarke, J.A. 2010b. Primobuccomcgrewi (Aves: Coracii) from the Eocene Green River Formation: New anatomical data from the earliest constrained record of stem rollers. Journal of Vertebrate Paleontology, 30:215-225.

Ksepka, D.T. and Clarke, J.A. 2010c. New fossil mousebird (Aves: Coliiformes) with feather preservation provides insight into the ecological diversity of an Eocene North American avifauna. Zoological Journal of the Linnean Society, 160:685-706.

Ksepka, D.T. and Clarke, J.A. 2012. A new stem parrot from the Green River Formation and the complex evolution of the grasping foot in Pan-Psittaciformes. Journal of Vertebrate Paleontology, 32:395-406.

Ksepka, D.T., Bertelli, S., and Giannini, N.P. 2006. The phylogeny of the living and fossil Sphenisciformes (penguins). Cladistics, 22:412-441.

Ksepka, D.T., Clarke, J.A., and Grande, L. 2011. Stem parrots (Aves, Halcyornithidae) from the Green River Formation and a combined phylogeny of PanPsittaciformes. Journal of Paleontology, 85:835-854.

Ksepka, D.T., Fordyce, R.E., Ando, T., and Jones, C.M. 2012. New fossil penguins (Aves: Sphenisciformes) from the Oligocene of New Zealand reveal the skeletal plan of stem penguins. Journal of Vertebrate Paleontology, 32:235-254.

Ksepka, D.T., Clarke, J.A., Nesbitt, S.J., Kulpe, F., and Grande, L. 2013. Fossil evidence of wing shape in a stem relative of swifts and hummingbirds (Aves, PanApodiformes). Proceedings of the Royal Society B, 280:20130580.

Ksepka, D.T., Benton, M.J., Carrano, M.T., Gandolfo, M.A., Head, J.J., Hermsen, E.J., Joyce, W.G., Lamm, K.S., Patané, J.S.L., Phillips, M.J., Polly, P.D., van Tuinen, M., Ware, J.L., Warnock, R.C.M., and Parham, J.F. 2011. Synthesizing and databasing fossil calibrations: divergence dating and beyond. Biology Letters, 7:801-803.

Kurochkin, E.N. and Dyke, G.J. 2010. A large collection of Presbyornis (Aves, Anseriformes, Presbyornithidae) from the late Paleocene and early Eocene of Mongolia. Geological Journal, 45:375-387.

Kurochkin, E.N., Dyke, G.J., and Karhu, A.A. 2002. A New Presbyornithid Bird (Aves, Anseriformes) from the Late Cretaceous of Southern Mongolia. American Museum Novitates, 3386:1-11.

Lebedinsky, N.G. 1927. Romainvillia stehlini n.g. n.sp., canard éocène provenant des marnes blanches du Bassin de Paris. Mémoires de la Société Paléontologique Suisse, 47:1-8.

Livezey, B.C. 1997. A phylogenetic analysis of basal Anseriformes, the fossil Presbyornis, and the interordinal relationships of waterfowl. Zoological Journal of the Linnean Society, 121:361-428. 
Livezey, B.C. and Zusi, R.L. 2006. Higher-order phylogenetics of modern birds (Theropoda, Aves: Neornithes) based on comparative anatomy. I. Methods and characters. Bulletin of the Carnegie Museum of Natural History, 37:1-544.

Livezey, B.C. and Zusi, R.L. 2007. Higher-order phylogeny of modern birds (Theropoda, Aves: Neornithes) based on comparative anatomy: II. Analysis and discussion. Zoological Journal of the Linnean Society, 149:1-95.

Louchart, A., Tourment, N., Carrier, J., Roux, T., and Mourer-Chauviré, C. 2008. Hummingbird with modern feathering: an exceptionally well-preserved Oligocene fossil from southern France. Naturwissenschaften, 95:171-175.

Marjanović, D. and Laurin, M. 2008. Assessing confidence intervals for stratigraphic ranges of higher taxa: The case of Lissamphibia. Acta Palaeontologica Polonica, 53:413-432.

Marshall, C.R. 1997. Confidence intervals on stratigraphic ranges with non-random distributions of fossil horizons. Paleobiology, 23:165-173.

Marshall, C.R. and Bleiweiss, R. 1999. Fossil gap analysis supports early Tertiary origin of trophically diverse avian orders: Comment and Reply. Geology, 27:9596.

Martin, J.E. 2006. Biostratigraphy of the Mosasauridae (Reptilia) from the Cretaceous of Antarctica. Geological Society, London, Special Publications, 258:101108.

Mayr, G. 1998. "Coraciiforme" und "piciforme" Kleinvögel aus dem Mittel-Eozän der Grube Messel (Hessen, Deutschland). Courier Forschungsinstitut Senckenberg 205:1-101.

Mayr, G. 2000a. New or previously unrecorded avian taxa from the Middle Eocene of Messel (Hessen, Germany). Mitteilungen aus dem Museum für Naturkunde in Berlin Geowissen Reihe, 3:207-219.

Mayr, G. 2000b. A new mousebird (Coliiformes: Coliidae) from the Oligocene of Germany. Journal fur Ornithologie, 141:85-92.

Mayr, G. 2001a. The relationships of fossil apodiform birds - a comment on Dyke (2001). Senckenbergiana Lethaea, 81:1-2.

Mayr, G. 2001b. Comments on the systematic position of the putative lower Eocene parrot Pulchrapollia gracilis. Senckenbergiana Lethaea, 81:339-341.

Mayr, G. 2002. On the osteology and phylogenetic affinities of the Pseudasturidae-Lower Eocene stemgroup representatives of parrots (Aves, Psittaciformes). Zoological Journal of the Linnean Society, 136:715-729.

Mayr, G. 2003. Phylogeny of early Tertiary swifts and hummingbirds (Aves: Apodiformes). Auk, 120:145151.

Mayr, G. 2004a. Old World Fossil Record of ModernType Hummingbirds. Science, 304:861-864.
Mayr, G. 2004b. The phylogenetic relationships of the early Tertiary Primoscenidae and Sylphornithidae and the sister taxon of crown group piciform birds. Journal of Ornithology, 145:188-198.

Mayr, G. 2005a. The Paleogene fossil record of birds in Europe. Biological Reviews, 80:515-542.

Mayr, G. 2005b. Tertiary plotopterids (Aves, Plotopteridae) and a novel hypothesis on the phylogenetic relationships of penguins (Spheniscidae). Journal of Zoological Systematics and Evolutionary Research, 10:1-11.

Mayr, G. 2005c. A new cypselomorph bird from the middle Eocene of Germany and the early diversification of avian aerial insectivores. Condor, 107:342-352.

Mayr, G. 2005d. New specimens of the Middle Eocene fossil mousebird Selmes absurdipes Peters 1999. Ibis, 143:427-434.

Mayr, G. 2006. New specimens of the Eocene Messelirrisoridae (Aves: Bucerotes), with comments on the preservation of uropygial gland waxes in fossil birds from Messel and the phylogenetic affinities of Bucerotes. Paläontologische Zeitschrift, 80:390-405.

Mayr, G. 2007. New specimens of the early Oligocene Old World hummingbird Eurotrochilus inexpectatus. Journal of Ornithology, 148:105-111.

Mayr, G. 2008a. Phylogenetic affinities and morphology of the late Eocene anseriform bird Romainvillia stehlini Lebedinsky, 1927. Neues Jahrbuch für Geologie und Paläontologie, Abhandlungen, 248:365-380.

Mayr, G. 2008b. Phylogenetic affinities of the enigmatic avian taxon Zygodactylus based on new material from the early Oligocene of France. Journal of Systematic Palaeontology, 6:333-344.

Mayr, G. 2009. Paleogene Fossil Birds. Springer, Heidelberg.

Mayr, G. 2010a. Phylogenetic relationships of the paraphyletic "caprimulgiform" birds (nightjars and allies). Journal of Zoological Systematics and Evolutionary Research, 48:126-137.

Mayr, G. 2010b. Reappraisal of Eocypselus - a stem group apodiform from the early Eocene of Northern Europe. Palaeobiodiversity and Palaeoenvironments, 9:395-403.

Mayr, G. 2011. Well-preserved new skeleton of the Middle Eocene Messelastur substantiates sister group relationship between Messelasturidae and Halcyornithidae (Aves, ?Pan-Psittaciformes). Journal of Systematic Palaeontology, 9:159-171.

Mayr, G. 2013a. The age of the crown group of passerine birds and its evolutionary significance - molecular calibrations versus the fossil record. Systematics and Biodiversity, 11: 7-13.

Mayr, G. 2013b. Late Oligocene mousebird converges on parrots in skull morphology. Ibis, 155:384-396.

Mayr, G. and Bertelli, S. 2011. A record of Rhynchaeites (Aves, Threskiornithidae) from the early Eocene Fur Formation of Denmark, and the affinities of the alleged parrot Mopsitta. Palaeobiodiversity and Palaeoenvironments, 91:229-236. 
Mayr, G. and Clarke, J. 2003. The deep divergences of neornithine birds: a phylogenetic analysis of morphological characters. Cladistics, 19:527-553.

Mayr, G. and Daniels, M. 1998. Eocene parrots from Messel (Hessen, Germany) and the London Clay of Walton-on-the-Naze (Essex, England). Senckenbergiana Lethaea, 78:157-177.

Mayr, G. and Micklich, N. 2008. New specimens of the avian taxa Eurotrochilus (Trochilidae) and Palaeotodus (Todidae) from the early Oligocene of Germany. Paläontologische Zeitschrift, 84:387-395.

Mayr, G. and Mourer-Chauviré, C. 2000. Rollers (Aves: Coraciiformes s.s.) from the Middle Eocene of Messel (Germany) and the Upper Eocene of the Quercy (France). Journal of Vertebrate Paleontology, 20:533546.

Mayr, G. and Mourer-Chauviré, C. 2004. Unusual tarsometatarsus of a mousebird from the Paleogene of France and the relationships of Selmes Peters, 1999. Journal of Vertebrate Paleontology, 24:366-372.

Mayr, G. and Peters, D.S. 1998. The mousebirds (Aves: Coliiformes) from the Middle Eocene of Grube Messel (Hessen, Germany. Senckenbergiana Lethaea, 78:179-197.

Mayr, G. and Peters, D.S. 1999. On the systematic position of the Middle Eocene swift Aegialornis szarskii Peters 1985 with description of a new swift-like bird from Messel (Aves, Apodiformes). Neues Jahrbuch für Geologie und Paläontologie, Monatshefte, 1999:312-320.

Mayr, G. and Smith, T. 2012. A fossil albatross from the Early Oligocene of the North Sea Basin. Auk, 129:8795.

Mayr, G., Manegold, A., and Johansson, U.S. 2003. Monophyletic groups within 'higher land birds' - comparison of morphological and molecular data. Journal of Zoological Systematics and Evolutionary Research, 41:223-248.

Mayr, G., Mourer-Chauviré, C., and Weidig, I. 2004. Osteology and systematic position of the Eocene Primobucconidae (Aves, Coraciiformes sensu stricto), with first records from Europe. Journal of Systematic Palaeontology, 2:1-12.

Mayr, G., Rana, R.S., Rose, K.D., Sahni, A., Kumar, K., Singh, L., and Smith, T. 2010. Quercypsitta-like birds from the early Eocene of India (Aves, ?Psittaciformes). Journal of Vertebrate Paleontology, 30:467478.

McGrew, P.O. and Feduccia, A. 1974. A preliminary report on a nesting colony of Eocene birds. Wyoming Geological Association Guidebook 1973:163-174.

Mertz, D.F., Harms, F.-J., Gabriel, G., and Felder, M. 2004. Arbeitstreffen in der Forschungsstation Grube Messel mit neuen Ergebnissen aus der Messel-Forschun. Natur und Museum, 134:289-290.

Milne-Edwards, A. 1867-1871. Recherches anatomiques et paléontologiques pour servir à l'histoire des oiseaux fossiles de la France. Masson, Paris.
Mlíkovsky, J. 1996. Tertiary avian localities of Denmark. Acta Universitatis Carolinae Geologica, 39:559-562.

Mlíkovsky, J. 2002. Cenozoic Birds of the World Part 1: Europe. Ninox Press, Prague.

Mlíkovský, J. and Göhlich, U.B. 2000. A new wood-hoopoe from the early Miocene of Germany and France. Acta Societatis Zoologicae Bohemiae, 64:419-424.

Morgan-Richards, M., Trewick, S.A., Bartosch-Härlid, A., Kardailsky, O., Phillips, M.J., McLenanchan, P.A., and Penny, D. 2008. Bird evolution: testing the Metaves clade with six new mitochondrial genomes. BMC Evolutionary Biology, 8:20.

Mourer-Chauviré, C. 1978. La poche á phosphate de Sainte-Néboule (Lot) et sa faune de vertébrés de Ludien supérieur. 6. Oiseaux. Palaeovertebrata, 8:217-229.

Mourer-Chauviré, C. 1985. Les Todidae (Aves, Coraciiformes) des Phosphorites du Quercy (France). Proceedings of the Koninklijke Nederlandse Akademie van Wetenschappen (Amsterdam), B, 88:407-411.

Mourer-Chauviré, C. 1988a. Les Aegialornithidae (Aves: Apodiformes) des Phosphorites du Quercy.Comparaison avec la forme de Messe. Courier Forschungsinstitut Senckenberg, 107:369-381.

Mourer-Chauviré, C. 1988b. Le gisement du Bretou (Phosphorites du Quercy, Tarn-et-Garonne, France) et sa faune de vertébrés de l'Eocène supérieur. II. Oiseaux. Palaeontographica (A), 205:29-50.

Mourer-Chauviré, C. 1992. Une nouvelle famille de Perroquets (Aves, Psittaciformes) dans l'Eocène supérieur des Phosphorites du Quercy. Geobios, 14:169-177.

Mourer-Chauviré, C. and Sigé, B. 2006. Une nouvelle espéce de Jungornis (Aves, Apodiformes) et de nouvelles formes de Coraciiformes s.s. dans l'Éocène supérieur du Quercy. Strata, 13:151-159.

Mourer-Chauviré, C., Berthet, D., and Hugueney, M. 2004. The late Oligocene birds of the Créchy quarry (Allier, France), with a description of two new genera (Aves: Pelecaniformes: Phalacrocoracidae, and Anseriformes: Anseranatidae). Senckenbergiana Lethaea, 84:303-315.

Müller, J. and Reisz, R.R. 2005. Four well-constrained calibration points from the vertebrate fossil record for molecular clock estimates. BioEssays, 27:10691075.

Myrcha, A., Jadwiszczak, P., Tambussi, C.P., Noriega, J.I., Gazdzicki, A., Tatur, A., and del Valle, R.A. 2002. Taxonomic revision of Eocene Antarctic penguins based on tarsometatarsal morphology. Polish Polar Research, 23:5-46.

Nesbitt, S.J., Ksepka, D.T., and Clarke, J.A. 2011. Podargiform affinities of the enigmatic Fluvioviridavis platyrhamphus and the early diversification of Strisores ("Caprimulgiformes" + Apodiformes). PLoS One, 6:e26350. 
Nessov, L.A. 1992. Mesozoic and Paleogene birds of the USSR and their paleoenvironments. Natural History Museum of Los Angeles County, Science Series, 36:465-478.

Ogg, J.G., Ogg, G., and Gradstein, F.M. 2008. The Concise Geologic Time Scale. Cambridge University Press, Cambridge, England.

Olson, S.L. 1975. Paleornithology of St. Helena Island, South Atlantic Ocean. Smithsonian Contributions to Paleobiology, 23:1-49.

Olson, S.L. 1976. Oligocene fossils bearing on the origins of the Todidae and the Momotidae (Aves: Coraciiformes). Smithsonian Contributions to Paleobiology, 27:111-119.

Olson, S.L. 1977. A Lower Eocene frigatebird from the Green River Formation of Wyoming (Pelecaniformes, Fregatidae). Smithsonian Contributions to Paleontology, 35:1-33.

Olson, S.L. 1985. The fossil record of birds, p. 79-238. In Farner, D.S., King, J.R., and Parkes, K.C. (eds.), Avian Biology. Academic Press, New York.

Olson, S.L. 1994. A giant Presbyornis (Aves: Anseriformes) and other birds from the Paleocene Aquia Formation of Maryland and Virginia. Proceedings of the Biological Society of Washington, 107:429-435.

Olson, S.L. 1999. The anseriform relationships of Anatalavis Olson and Parris (Anseranatidae), with a new species from the Lower Eocene London Clay. Smithsonian Contributions to Paleobiology, 89:231-243.

Olson, S.L. and Feduccia, A. 1979. An Old World occurrence of the Eocene avian family Primobucconidae. Proceedings of the Biological Society of Washington, 92:494-497.

Olson, S.L. and Feduccia, A. 1980. Presbyornis and the origin of the Anseriformes (Aves: Charadriomorphae). Smithsonian Contributions to Zoology, 323:124.

Olson, S.L. and Parris, D.C. 1987. The Cretaceous birds of New Jersey. Smithsonian Contributions to Paleobiology, 63:1-22.

Pacheco, M.A., Battistuzzi, F.U., Lentino, M., Aguilar, R.F., Kumar, S., and Escalante, A.A. 2011. Evolution of modern birds revealed by mitogenomics: timing the radiation and origin of major orders. Molecular Biology and Evolution, 28:1927-1942.

Parham, J.F., Donoghue, P.C.J., Bell, C.J., Calway, T.D., Head, J.J., Holroyd, P.A., Inoue, J.G., Irmis, R.B., Joyce, W.G., Ksepka, D.T., Patané, J.S.L., Smith, N.D., Tarver, J.E., Van Tuinen, M., Yang, Z., Angielczyk, K.D., Greenwood, J., Hipsley, C.A., Jacobs, L., Makovicky, P.J., Müller, J., Smith, K.T., Theodor, J.M., Warnock, R.C.M., and Benton, M.J. 2012. Best practices for justifying fossil calibrations. Systematic Biology, 61:346-359.
Parris, D.C. and S. Hope. 2002. New Interpretations of Birds from the Navesink and Hornerstown Formations, New Jersey, USA (Aves: Neornithes), p. 113124. In Zhou, Z. and Zhang, F. (eds.), Proceedings of the 5th Symposium of the Society of Avian Paleontology and Evolution, Beijing, 1-4 June 2000. Science Press, Beijing, China.

Penny, D. and Phillips, M.J. 2004. The rise of birds and mammals: are microevolutionary processes sufficient for macroevolution? Trends in Ecology and Evolution, 19:516-522.

Pereira, S.L., Johnson, K.P., Clayton, D.H., and Baker, A.J. 2007. Mitochondrial and Nuclear DNA Sequences Support a Cretaceous Origin of Columbiformes and a Dispersal-Driven Radiation in the Paleogene. Systematic Biology, 56:656-672.

Peters, D.S. 1985. Ein neuer Segler aus der Grube Messel und seine Bedeutung für den Status der Aegialornithidae (Aves: Apodiformes). Senckenbergiana Lethaea, 66:143-164.

Peters, D.S. 1999. Selmes absurdipes, new genus, new species, a sandcoleiform bird from the oil shale of Messel (Germany, middle Eocene). Smithsonian Contributions to Paleobiology, 89:217-222.

Peters, D.S. and Hamedani, A. 2000. Frigidafons babaheydariensis n. sp., ein Sturmvogel aus dem Oligozän des Irans (Aves: Procellariidae). Senckenbergiana Lethaea, 80:29-37.

Phillips, M.J., Gibb, G.C., Crimp, E.A., and Penny, D. 2010. Tinamous and moa flock together: mitochondrial genome sequence analysis reveals independent losses of flight among ratites. Systematic Biology, 59:90-107.

Pirrie, D., Crame, J., and Riding, J. 1991. Late Cretaceous stratigraphy and sedimentology of Cape Lamb, Vega Island, Antarctica. Cretaceous Research, 12:227-258.

Pirrie, D., Crame, J., Lomas, S., and Riding, J. 1997. Late Cretaceous stratigraphy of the Admiralty Sound region, James Ross Basin, Antarctica. Cretaceous Research, 18:109-137.

Pratt, R.C., Gibb, G.C., Morgan-Richards, M., Phillips, M.J., Hendy, M.D., and Penny, D. 2009. Toward resolving deep Neoaves phylogeny: data, signal enhancement, and priors. Molecular Biology and Evolution, 26:313-326.

Pyron, R.A. 2011. Divergence time estimation using fossils as terminal taxa and the origins of Lissamphibia. Systematic Biology, 60:466-481.

Reisz, R.R. and Müller, J. 2004. Molecular timescales and the fossil record: a paleontological perspective. Trends in Genetics, 20:237-241.

Renne, P.R., Deino, A.L., Hilgen, F.J., Kuiper, K.F., Mark, D.F., Mitchell III, W.S., Morgan, L.E., Mundil, R., and Smit, J. 2013. Time scales of critical events around the Cretaceous-Paleogene boundary. Science, 339:684-687. 
Rhodes, G.M., Ali, J.R., Hailwood, E.A., King, C., and Gibson, T.G. 1999. Magnetostratigraphic correlation of Paleogene sequences from northwest Europe and North America. Geology, 27:451-454.

Rich, P.V. and Bohaska, D.J. 1976. The world's oldest owl: a new strigiform from the Paleocene of southwestern Colorado. Smithsonian Contributions to Paleobiology, 5:95-102.

Rich, P.V. and Haarhoff, P.J. 1985. Early Pliocene Coliidae (Aves, Coliiformes) from Langebaanweg, South Africa. Ostrich, 56:20-41.

Riding, J.B., Keating, J.M., Snape, M.G., Newham, S., and Pirrie, D. 1992. Preliminary Jurassic and Cretaceous dinoflagellate cyst stratigraphy of the James Ross Island area, Antarctic Peninsula. Newsletters on Stratigraphy, 26:19-39.

Ronquist, F., Klopfstein, S., Vilhelmsen, L., Schulmeister, S., Murray, D.L., and Rasnitsyn, A.P. 2012. A totalevidence approach to dating with fossils, applied to the early radiation of the Hymenoptera. Systematic Biology, 61:973-999.

Schmidt-Kittler, N. 1987. European reference levels and correlation tables. Münchner Geowissenschaftliche Abhandlungen, Reihe A, Geologie und Paläontologie, 10:13-19.

Secord, R., Gingerich, P.D., Smith, M.E., Clyde, W.C., Wilf, P., and Singer, B.S. 2006. Geochronology and mammalian biostratigraphy of middle and upper Paleocene continental strata, Bighorn Basin, Wyoming. American Journal of Science, 306:211-245.

Shapiro, B., Sibthorpe, D., Rambaut, A., Austin, J., Wragg, G.M., Bininda-Emonds, O.R.P., Lee, P.L.M., and Cooper, A. 2002. Flight of the Dodo. Science 295:1683.

Slack, K.E., Janke, A., Penny, D., and Arnason, U. 2003. Two new avian mitochondrial genomes (penguin and goose) and a summary of bird and reptile mitogenomic features. Gene, 302:43-52.

Slack, K.E., Jones, C.M., Ando, T., Harrison, G.L., Fordyce, R.E., Arnason, U., and Penny, D. 2006. Early penguin fossils, plus mitochondrial genomes, calibrate avian evolution. Molecular Biology and Evolution, 23:1144-1155.

Smith, M.E., Carroll, A.R., and Singer, B.S. 2008. Synoptic reconstruction of a major ancient lake system: Eocene Green River Formation, western United States. Geological Society of American Bulletin 120:54-84.

Smith, N.A. in press. The fossil record and phylogeny of the auklets (Pan-Alcidae, Aethiini). Journal of Systematic Palaeontology.

Smith, N.D. 2010. Phylogenetic analysis of Pelecaniformes (Aves) based on osteological data: implications for waterbird phylogeny and fossil calibration studies. PLoS ONE, 5:e13354.

Sorenson, M.D., Oneal, E., García-Moreno, J., and Mindell, D.P. 2003. More taxon, more characters: the hoatzin problem is still unresolved. Molecular Biology and Evolution, 20:1484-1498.
Stidham, T.A. 1998. A lower jaw from a Cretaceous parrot. Nature, 396:29-30.

Stidham, T.A. 1999. Did parrots exist in the Cretaceous period? Reply. Nature, 399:318.

Strauss, D. and Sadler, P.M. 1989. Classical confidence intervals and Bayesian probability estimates for the ends of local taxon ranges. Mathematical Geology, 21:411-427.

Suh, A., Paus, M., Kiefmann, M., Churakov, G., Franke, F.A., Brosius, J., Kriegs, J.O., and Schmitz, J. 2011. Mesozoic retroposons reveal parrots as the closest living relatives of passerine birds. Nature Communications, 2:443.

Tambussi, C.P. and Tonni, E.P. 1988. Un Diomedeidae (Aves: Procellariiformes) del Eoceno tardío de la Antártida. Jornadas Argentinas de Paleontología de Vertebrados, 5:34-35.

Tambussi, C.P., Acosta Hospitaleche, C.I., Reguero, M.A., and Marenssi, S.A. 2006. Late Eocene penguins from West Antarctica: systematics and biostratigraphy. Geological Society, London, Special Publications, 258:145-161.

Tambussi, C.P., Reguero, M.A., Marenssi, S.A., and Santillana, S.N. 2005. Crossvalia unienwillia, a new Spheniscidae (Sphenisciformes, Aves) from the late Paleocene of Antarctica. Geobios, 38:667-675.

Thiede, J., Nielsen, O.B., and Perch-Nielsen, K. 1980. Lithofacies, mineralogy and biostratigraphy of Eocene sediments in northern Denmark (Deep test Viborg 1). Neues Jahrbuch für Geologie und Paläontologie, Abhandlungen, 160:149-172.

Thomas, D.B., Ksepka, D.T., and Fordyce, R.E. 2011. Penguin heat retention structures evolved in a Greenhouse Earth. Biology Letters, 7:461-464.

Thorne, J.L., Kishino, H., and Painter, I.S. 1998. Estimating the rate of evolution of the rate of molecular evolution. Molecular Biology and Evolution, 15:16471657.

Thorn, V.C., Riding, J.B., and Francis, J.E. 2009. The Late Cretaceous dinoflagellate cyst Manumiella: Biostratigraphy, systematics, and palaeoecological signals in Antarctica. Review of Palaeobotany and Palynology, 156:436-448.

Tobin, T.S., Ward, P.D., Steig, E.J., Olivero, E.B., Hilburn, I.A., Mitchell, R.N., Diamond, M.R., Raub, T.D., and Kirschvink, J.L. 2012. Extinction patterns, $\delta 180$ trends, and magnetostratigraphy from a southern high-latitude Cretaceous-Paleogene section: Links with Deccan volcanism. Palaeogeography, Palaeoclimatology, Palaeoecology, 350-352:180-188.

van Tuinen, M. and Hedges, S. 2001. Calibration of avian molecular clocks. Molecular Biology and Evolution, 18:206-213.

van Tuinen, M. and Dyke, G. 2004. Calibration of galliform molecular clocks using multiple fossils and genetic partitions. Molecular Phylogenetics and Evolution, 30:74-86. 
van Tuinen, M., Ramakrishnan, U., and Hadly, E.A. 2004. Investigating the effect of environmental change on biotic evolution: genetic contributions, current work and future developments. Philosophical Transactions of the Royal Society of London, Series A, 362:2795-2820.

Wang, W., Braun, E.L., and Kimball, R.T. 2012. Testing hypotheses about the sister group of the Passeriformes using an independent 30-locus data set. Molecular Biology and Evolution, 29:737-750.

Ware, J., Grimaldi, D., and Engel, M. 2010. The Effects of Fossil Placement and Calibration on Divergence Times and Rates: An example from the Termites (Insecta: Isoptera). Arthropod Structure and Development, 38:204-219.

Warnock, R.C.M., Yang, Z., and Donoghue, P.C.J. 2012. Exploring uncertainty in the calibration of the molecular clock. Biology Letters, 8:156-159

Watanabe, M., Nikaido, M., Tsuda, T.T., Kobayashi, T., Mindell, D., Cao, Y., Okada, N., and Hasegawa, M. 2006. New candidate species most closely related to penguins. Gene, 378: 65-73.

Waterhouse, D.M., Lindow, B.E.K., Zelenkov, N.V., and Dyke, G.J. 2008. Two new parrots (Psittaciformes) from the Lower Eocene Fur Formation of Denmark. Palaeontology, 51:575-582.

Westerhold, T., Röhl, U., Laskar, J., Raffi, I., Bowles, J., Lourens, L.J., and Zachos, J.C. 2007. On the duration of magnetochrons $\mathrm{C} 24 \mathrm{r}$ and $\mathrm{C} 25 \mathrm{n}$ and the timing of early Eocene global warming events: Implications from the Ocean Drilling Program Leg 208 Walvis Ridge depth transect. Paleoceanography, 22:PA2201.
White, N.E., Phillips, M.J., Gilbert, M.T.P., Alfaro-Núñez, A., Willerslev, E., Mawson, P.R., Spencera, P.B.S., and Bunce, M. 2011. The evolutionary history of cockatoos (Aves: Psittaciformes: Cacatuidae). Molecular Phylogenetics and Evolution, 593:615622.

Wijnker, E. and Olson, S.L. 2009. A revision of the fossil genus Miocepphus and other Miocene Alcidae (Aves: Charadriiformes) of the Western North Atlantic Ocean. Journal of Systematic Palaeontology 7:471487.

Worthy, T.H. and Scanlon, J. 2009. An Oligo-Miocene Magpie Goose (Aves:Anseranatidae) from Riversleigh, north western Queensland, Australia. Journal of Vertebrate Paleontology, 25:205-211.

Yang, Z. 2007. PAML 4: Phylogenetic Analysis by Maximum Likelihood. Molecular Biology and Evolution, 24:1586-1591.

Yang, F.L. and Rananala, B. 2006. Bayesian estimation of species divergence times under a molecular clock using multiple fossil calibrations with soft bounds. Molecular Biology and Evolution, 23:212-226.

Yuri, T., Kimball, R.T., Harshman, J., Bowie, R.C.K., Braun, M.J., Chojnowski, J.L., Han, K.-L., Hackett, S.J., Huddleston, C.J., Moore, W.S., Reddy, S., Sheldon, F.H., Steadman, D.W., Witt, C.C., and Braun, E.L. 2013. Parsimony and model-based analyses of indels in avian nuclear genes reveal congruent and incongruent phylogenetic signals. Biology, 2:419444.

Zelenkov, N.V. and Dyke, G.J. 2008. The fossil record and evolution of mousebirds (Aves: Coliiformes). Palaeontology, 51:1403-1418. 